\title{
Absolute transport estimates of total and individual water masses in the northern Greenland Sea derived from hydrographic and acoustic Doppler current profiler measurements
}

\author{
Boris Cisewski, Gereon Budéus, and Gunther Krause \\ Alfred-Wegener-Institut für Polar- und Meeresforschung, Bremerhaven, Germany
}

Received 8 July 2002; revised 12 February 2003; accepted 18 June 2003; published 18 September 2003.

[1] Conductivity-temperature-depth transects across the Greenland Sea and Fram Strait provide geostrophic shear velocity profiles, which were absolutely referenced using the simultaneous measurements from a vessel-mounted acoustic Doppler current profiler. The measurements are performed mainly in 1997, with supplements in 1998, 1995, and 1994. The observations confirm that all currents within the area have a strong barotropic component so that calculations based on the geostrophic method underestimate the transports considerably. Particulars for the transports of mass and heat are given for all individual and total water masses in the area. Meanders and eddies on horizontal scales between 20 and $70 \mathrm{~km}$ affect the total transport in the West Spitsbergen Current significantly. The Atlantic Water transports range between 2 and 7 Sv, mainly dominated by the cross-sectional area occupied by this water mass. The total northward heat transport across $75^{\circ} \mathrm{N}$ is estimated as $54.7 \mathrm{TW}$ and across $79^{\circ} 40^{\prime} \mathrm{N}$ as $42 \mathrm{TW}$ in September 1997. INDEX TERMS: 4223 Oceanography: General: Descriptive and regional oceanography; 4283 Oceanography: General: Water masses; 4512 Oceanography: Physical: Currents; 4532 Oceanography: Physical: General circulation; KEYWORDS: Greenland Sea, circulation, transports, West Spitsbergen Current, East Greenland Current, ADCP

Citation: Cisewski, B., G. Budéus, and G. Krause, Absolute transport estimates of total and individual water masses in the northern Greenland Sea derived from hydrographic and acoustic Doppler current profiler measurements, J. Geophys. Res., 108(C9), 3298, doi:10.1029/2002JC001530, 2003.

\section{Introduction}

[2] Fram Strait between Greenland and Spitsbergen is the only deep-water connection between the Arctic and the World's ocean. Aagaard and Greisman [1975] have estimated that $\sim 75 \%$ of the mass exchange and $90 \%$ of the net heat transfer occur through this $600 \mathrm{~km}$ wide and $2600 \mathrm{~m}$ deep passage.

[3] Two boundary currents link the North Atlantic with the Arctic Ocean. On the eastern side, the West Spitsbergen Current (WSC) carries warm and salty water of Atlantic origin into the Arctic Ocean providing an important heat sink for the North Atlantic, and represents the main heat source for the Polar Basin. On the western side, the East Greenland Current (EGC) carries ice and cold low-salinity water southward.

[4] Although the large-scale circulation in this region is well known from the comprehensive works of HellandHansen and Nansen [1909], Alekseev and Istoshin [1960], Carmack [1972], Trangeled [1974], and Koltermann [1991], a lack of knowledge concerning the absolute velocities, their temporal variability and spatial structure still exists. Until the early 1970s almost all transport estimates of both boundary currents used the geostrophic method for

Copyright 2003 by the American Geophysical Union. 0148-0227/03/2002JC001530\$09.00 which the determination of a reference level has always been problematic [Hill and Lee, 1957; Kislyakov, 1960; Timofeyev, 1962].

[5] First indications for considerable barotropic components in the WSC resulted from a long time series of moored current meter measurements since 1971. They revealed that the yearly averaged transports were $\sim 2-4$ times larger than the previous estimates [Greisman, 1976]. Hanzlick [1983] pointed out that the flow of the WSC has a significant lateral structure and exhibits a large variability over a broad range of timescales.

[6] Foldvik et al. [1988] observed that also half of the transport of the EGC near $79^{\circ} \mathrm{N}$ is barotropic. They used yearlong moored current meters and recognized a considerable mesoscale current structure. In the following years many additional moorings were deployed in Fram Strait to obtain better insights into the dynamics of the currents and their transports. Between 1987 and 1994, Fahrbach et al. [1995] deployed current meter moorings in the East Greenland Current at $75^{\circ} \mathrm{N}$. They estimated the volume transport south across $75^{\circ} \mathrm{N}$ over a horizontal distance of $140 \mathrm{~km}$ as $25 \mathrm{~Sv}$.

[7] Woodgate et al. [1999] continued this study and calculated the annual mean transport for the time period $1994-1995$ as $21 \pm 3 \mathrm{~Sv}$, varying from $11 \mathrm{~Sv}$ in summer to $37 \mathrm{~Sv}$ in winter.

[8] A problem with this type of point measurements is the coarse resolution. Hydrographic sections in this region 
Table 1. Cruise Data

\begin{tabular}{lccc}
\hline & \multicolumn{2}{c}{ Date } & \\
\cline { 2 - 3 } \multicolumn{1}{c}{ Cruise } & \multicolumn{1}{c}{ Start } & End & Instrument \\
\hline ARK X/1 & 6 July 1994 & 15 Aug. 1994 & SBE 911+ \\
ARK XI/2 & 22 Sep. 1995 & 29 Oct. 1995 & SBE 911+ \\
ARK XIII/3 & 13 Aug. 1997 & 29 Sep. 1997 & SBE 911+ \\
ARK XIV/2b & 27 Aug. 1998 & 15 Oct. 1998 & SBE 911+ \\
\hline
\end{tabular}

[Budéus et al., 1993] and float trajectories [Gascard et al., 2002] reveal spatial structures of the order of only $10-20 \mathrm{~km}$ horizontally. This points to eddies and meanders on similar scales, the contribution of which to transport calculations cannot be resolved by current meters.

[9] In order to explore the spatial velocity structures of such small dimensions, we have used a ship-mounted acoustic Doppler current profiler (ADCP) on several expeditions of RV Polarstern since 1993. The resulting absolute velocity field within the uppermost $400 \mathrm{~m}$ is used together with a comprehensive hydrographic data set to provide an absolute reference for geostrophic current and transport estimations of mass and heat [Cisewski, 2001]. This method provides a quasi-synoptic snapshot of the spatial velocity field at the time of observation, and in this article we use such images for the summers of 1997 and 1998 to calculate the velocities and transports of all water masses in the area.

\section{Data and Methods}

\subsection{Conductivity-Temperature-Depth (CTD) Profiler}

[10] The hydrographic database consists of 285 conductivity-temperature-depth (CTD) stations obtained in the Greenland Sea, Fram Strait and the western Barents Sea opening sampled between July 1994 and September 1998 from R.V. Polarstern (Table 1).

[11] Four transects across the Greenland Sea at $75^{\circ} \mathrm{N}$ have been performed during the summer periods of 1994-1998. Moreover, in 1997 hydrographic measurements were made at $79^{\circ} 40^{\prime} \mathrm{N}$, in Fram Strait, and at $18^{\circ} \mathrm{E}$, on the Barents Sea shelf. Station spacing for the full-depth hydrographic profiles was typically $20 \mathrm{~km}$, with closer spacing $(10 \mathrm{~km})$ near the East Greenland Polar Front (EGPF) and the Arctic Front (AF). Study area and station locations are shown in Figure 1. The instruments were calibrated immediately before and after the cruise. For in situ calibration, temperatures were measured with reversing thermometers, and salinity samples

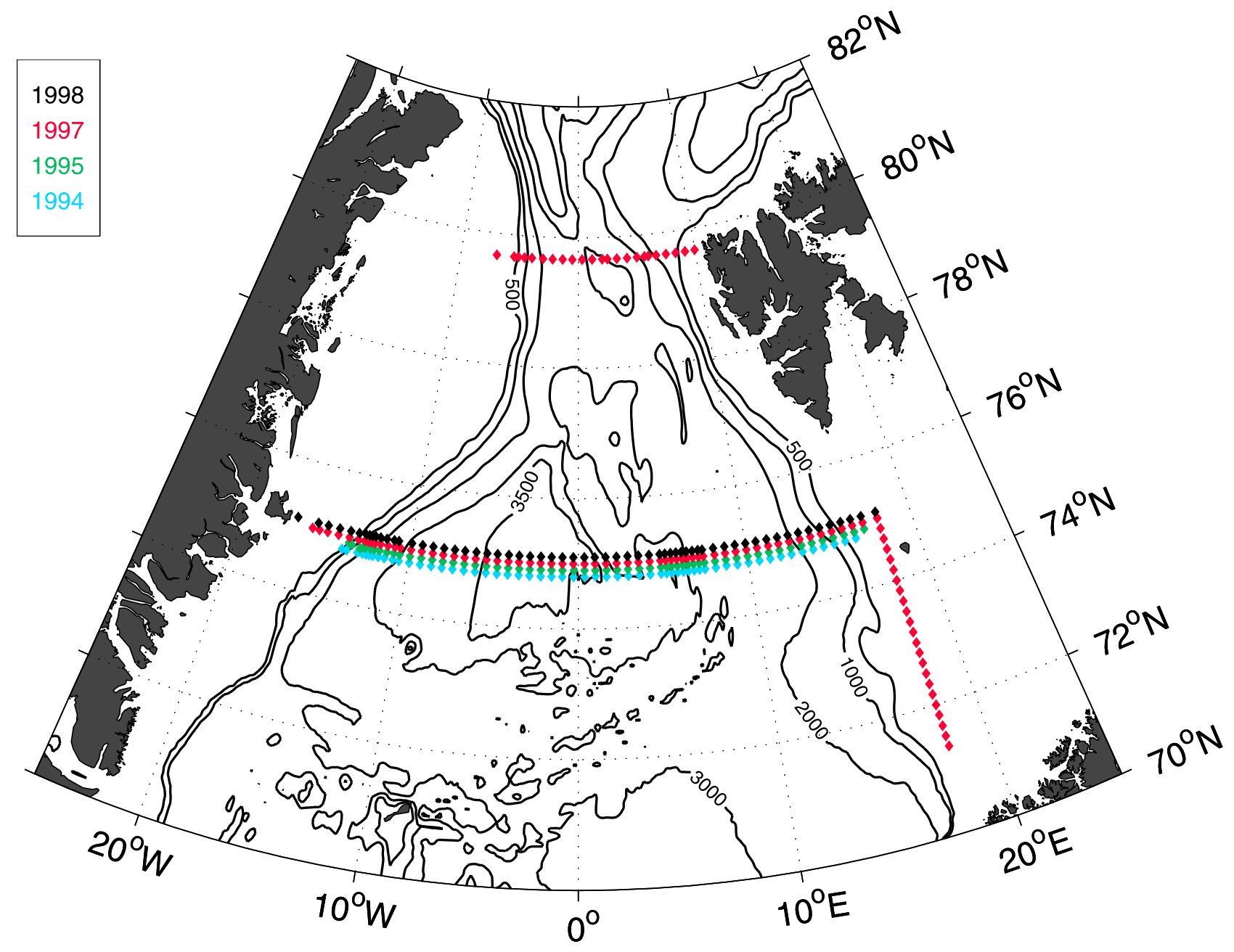

Figure 1. Hydrographic stations performed between 1994 and 1998. The primary data set consists of 1997 and 1998 data. 
were analyzed with a Guildline salinometer onboard. Data processing is done by standard oceanographic methods. Vertical averages over $1 \mathrm{dbar}$ form the basis of this hydrographic data set. The calibration steps are described by Budéus and Schneider [1998].

\subsection{Acoustic Doppler Current Profiler (ADCP)}

[12] During the listed surveys current velocities were measured continuously along the ship's track with an RD Instruments, vessel-mounted, 153.6-kHz ADCP. However, the $75^{\circ} \mathrm{N}$ surveys of 1994 and 1995 were excluded from this study because of big spatial data gaps.

[13] The transducers are located $11 \mathrm{~m}$ under water and are protected against ice floes by an acoustic window. The depth range of the ADCP is mostly determined by the abundance of scatterers and the presence of air bubbles under the transducer, and varies between 250 and 400 meters. The current measurements were made using a pulse and vertical bin length of $8 \mathrm{~m}$. The sampling interval was either 60 or 120 s. Bad data were rejected when the percent-good criterion fell below $80 \%$. The reference layer was set to bins $10-15$ avoiding near surface affects and biases near bin 1.

[14] Heading, roll and pitch data from the ship's gyrocompass were used to convert the ADCP velocities into earth coordinates. The ship's velocity was calculated from position fixes obtained by the Global Positioning System (GPS) or DGPS if available. Accuracy of the absolute velocities varies from cruise to cruise, mainly depending on the quality of the position fixes and the ship's heading data. With DGPS, available for 1997 and 1998, errors of the ship velocity are $1 \mathrm{~cm} \mathrm{~s}^{-1}$. Further errors stem from a misalignment of the transducer with the ship's centerline. To correct these errors we calibrated using the techniques described by Joyce [1989] and Pollard and Read [1989]. The resultant misalignment angle $(\varphi)$ and the scaling factor (A) amount to $0.68^{\circ}$ and $0.76^{\circ}$, and 1.01 and 1.02 in 1997 and 1998, and velocities have been corrected accordingly. The ADCP data were processed using CODAS3 software.

\subsection{Deriving Absolute Velocities}

[15] According to the referencing method presented by Pickart and Lindstrom [1994], we combine the ADCP data with the geostrophic currents derived from the hydrographic measurements. From a variety of current meters deployed in Fram Strait [Greisman, 1976; Hanzlick, 1983; Foldvik et al., 1988; Fahrbach et al., 2001] and in the Greenland Sea [Fahrbach et al., 1995; Woodgate et al., 1999], we know that the boundary currents include a strong barotropic component, so that a level of no motion does not exist.

[16] To obtain the ADCP-referenced geostrophy, the normal component of the ADCP currents was spatially averaged between the CTD casts, so that ADCP velocities are available at the same locations of geostrophic profiles. The geostrophic velocities, which were always calculated relative to the deepest common level of each station pair, were adjusted to fit the normal ADCP velocity component for a specified depth range. A suitable depth range is characterized by a close agreement between the vertical shear profiles determined from both data sets. In this case the depth range was set to $199-253 \mathrm{~m}$, to avoid effects both from surface forcing and weak signals close to the range limit. Also, the averaged barotropic offset reveals a small standard deviation there. The spatial resolution of the derived absolute velocity field is $8 \mathrm{~m}$ in the vertical and 10 to $20 \mathrm{~km}$ horizontally, the latter being determined by the station distances.

[17] According to the original data set the total volume transport across $75^{\circ} \mathrm{N}$ is $0.3 \pm 23.1 \mathrm{~Sv}$ in September 1997. In order to make meaningful estimates of large-scale heat transports, a small constant offset has been applied to the 1997 velocity data in such a manner that the net volume transports across $75^{\circ} \mathrm{N}$ and $79^{\circ} 40^{\prime} \mathrm{N}$ amount to $-1.6 \mathrm{~Sv}$, which means that the total transport over the rims of the transport box (including the Barents Sea transect) is balanced.

[18] The total volume transport across $75^{\circ} \mathrm{N}$ is $-15 \pm$ 23.1 Sv in September 1998 (negative values indicate southward transports). As indicated by the error margins, this is not significantly different from the expected balance of approximately zero transport because with the large cross-sectional area covered by the measurements, already small velocity deviations lead to seemingly big errors in the transport estimates. A net southward transport of $-15 \mathrm{~Sv}$ could be due, e.g., to the nonperfect synopticity of the transect or to errors induced by a slightly inaccurate estimate of the misalignment angle. Since there is no complete transport box measured in 1998, a constant velocity offset of $6.5 \mathrm{~mm}$ $\mathrm{s}^{-1}$ is applied to the geostrophic velocities to adjust the total transport across $75^{\circ} \mathrm{N}$ to about zero.

\subsection{Heat Fluxes}

[19] The simultaneous measurements of velocities and hydrographical parameters allow for a reliable method of heat transport calculations. The hydrographic data are averaged over the same vertical distance as the ADCP bin size (i.e., $8 \mathrm{~m}$ ) and are linearly interpolated between station pairs so that both velocity and temperature data sets exist on the same grid, which is constructed by the $8 \mathrm{~m}$ vertical bin size and the halfway station distance to each side. Thus calculations can be performed for every individual bin, avoiding inaccuracies stemming from the use of averages over larger areas. All transports are estimated by summing up these individual bin products. It is evident that the small station spacing is advantageous for this. The reference temperature for heat transport calculations is chosen as $-0.1^{\circ} \mathrm{C}$ in accordance with Aagaard and Greisman [1975]. Since we will construct later a transport box with zero net mass transport across its boundaries, this choice of reference temperature is irrelevant for the total heat budget. However, heat fluxes of individual water masses are affected by this choice.

\section{Results and Discussion}

[20] Three hydrographic sections performed during August and September 1997, which cover the area of the central Greenland Sea, Fram Strait and the Barents Sea opening were used to obtain a near synoptic picture of the hydrographic structure, circulation, and transports of the entire region.

\subsection{Water Mass Structure}

[21] Before going into a detailed discussion we summarize the $\Theta / S$ characteristics of all observed water 
Table 2a. Water Mass Characteristics of the Greenland Sea

\begin{tabular}{lcl}
\hline \multicolumn{1}{c}{ Layer } & Acronym & \multicolumn{1}{c}{ Definitions } \\
\hline Surface & PW & $\Theta<0^{\circ} \mathrm{C} ; S<34.7$ \\
& ASW & $0^{\circ} \mathrm{C}<\Theta<1{ }^{\circ} \mathrm{C} ; S<34.7 ; \Theta>1{ }^{\circ} \mathrm{C} ; S<34.9$ \\
& AW & $\Theta>3^{\circ} \mathrm{C} ; S>34.9$ \\
Intermediate & RAW & $\Theta>0^{\circ} \mathrm{C} ; S>34.9$ \\
& UAIW & $\Theta<1^{\circ} \mathrm{C} ; 34.7<S<34.9$ \\
& LAIW & $0^{\circ} \mathrm{C}<\Theta<3{ }^{\circ} \mathrm{C} ; S>34.9$ \\
Deep & AODW & $S_{\max }(S>34.91)$ in DW \\
& DW & $\sigma_{2}<37.457 ;-1.2^{\circ} \mathrm{C}<\Theta<-0.5 ; S<34.92$ \\
Bottom & GSBW & $\sigma_{2}>37.457$ \\
\hline
\end{tabular}

masses in Tables $2 \mathrm{a}$ and $2 \mathrm{~b}$. Representative $\Theta / S$ relations are shown for the western and eastern periphery of the Greenland Sea in Figures 2a and 2b. In our nomenclature we follow mostly the definitions of Swift and Aagaard [1981].

\subsubsection{Greenland Sea}

[22] The transect at $75^{\circ} \mathrm{N}$ extends from $16^{\circ} \mathrm{W}$ to $18^{\circ} \mathrm{E}$ (Figures $3 \mathrm{a}$ and $3 \mathrm{~b}$ ) and covers the entire area between the East Greenland and Barents Sea shelves. The hydrographic conditions in the upper layer show the same main largescale features of the Greenland Sea gyre as proposed by Carmack [1972], Carmack and Aagaard [1973], Swift and Aagaard [1981], and Swift [1986]. Along the $75^{\circ} \mathrm{N}$ section a four-layer structure is found. The upper two layers are separated by $\sigma_{\Theta}=27.9$.

[23] The upper layer mainly consists of three water masses, namely Polar Water (PW), Arctic Surface Water (ASW) and Atlantic Water (AW). Between $16^{\circ} \mathrm{W}$ and $12^{\circ} \mathrm{W}$ the upper $200 \mathrm{~m}$ are occupied by cold and fresh PW. Owing to a high melting rate during the summer season the salinity there decreases to a minimum salinity of 30 close to the surface.

[24] Strong horizontal gradients both in salinity and temperature mark the position of the East Greenland Polar Front (EGPF) representing the eastern boundary of the polar domain. To the east of the front, return Atlantic Water (RAW) is found in depths between 30 and $400 \mathrm{~m}$, which is carried by the East Greenland Current (EGC) southward. This water mass is characterized by a salinity and temperature maximum. Further east, in the Arctic domain, the upper layer consists of a 30-50 m thin surface layer of ASW. The eastern periphery of this transect is dominated by a core of warm and salty Atlantic Water (AW) extending from $6^{\circ} \mathrm{E}$ to $16^{\circ} \mathrm{E}$ horizontally and from the surface to $700 \mathrm{~m}$ vertically. Decreasing salinities in the surface layer of the easternmost stations indicate the mixture with low-salinity waters probably of Barents Sea origin [Hopkins, 1991]. The intermediate layer of the central Greenland Sea, separated by $\sigma_{\Theta}=27.9$ from the upper and by $\sigma_{1}=32.8$ from the deep layers is associated with the Upper Arctic Intermediate Water (UAIW).

[25] The deep-water layer, separated from the bottom layer by $\sigma_{2}=37.457$, consists of Arctic Ocean Deep Water (AODW), Greenland Sea Deep Water (GSDW) and Norwegian Sea Deep Water (NSDW). Over the East Greenland continental slope the Arctic outflow of Deep water masses can be traced by an intermediary salinity maximum $(S>34.91)$ between 1500 and 2500 meters. Contrasting with prior studies [Swift and Aagaard, 1981; Aagaard et al., 1985] we cannot distinguish the GSDW from the NSDW by means of temperature and salinity. Hence we apply the term Deep Water (DW*), which involves GSDW and NSDW.

[26] Below $2500 \mathrm{~m}$, down to the bottom, the densest water mass of the Northern Hemisphere, the Greenland Sea Bottom Water (GSBW), is found.

\subsubsection{Fram Strait}

[27] The zonal Fram Strait transect is located at $79^{\circ} 40^{\prime} \mathrm{N}$ (Figures $4 \mathrm{a}$ and $4 \mathrm{~b}$ ). Here, PW is found in the upper layer between the stations 33 and 44. East of the EGPF the upper $50 \mathrm{~m}$ consist of a warm and less salty surface layer, and the AW is not at the surface any longer. The Atlantic water core extends from $0^{\circ} \mathrm{E}$ to $10^{\circ} \mathrm{E}$ horizontally and down to $600 \mathrm{~m}$ vertically. Again, the temperature and salinity maximum is found close to the Spitsbergen coast. The deep layers are dominated by a salinity increase toward the bottom indicating the presence of EBDW.

[28] Between $7^{\circ} \mathrm{W}$ and $2^{\circ} \mathrm{W}$ modified Atlantic Water (MAW) with salinities and temperatures ranging between 34.5 and 34.9 and $0^{\circ}$ and $3^{\circ} \mathrm{C}$ mark the Arctic outflow of Atlantic Water masses as proposed by Rudels [1987]. Below the MAW, salinity increases and temperature decreases over a vertical distance of $\sim 500 \mathrm{~m}$ representing the Upper Polar Deep water (UPDW). The deep-water layer shows two distinct salinity maxima in $1600-1800 \mathrm{~m}$ and $2300 \mathrm{~m}$, which we recognize as Canadian Basin Deep water (CBDW) and Eurasian Basin Deep water (EBDW), corresponding to the results from Meincke et al. [1997].

\subsubsection{Barents Sea Opening}

[29] We define the meridional section on the Barents Sea shelf between Bear Island and $71^{\circ} \mathrm{N}$ as the entrance of the AW onto the Barents Sea shelf. In September 1997 a northsouth transect at $18^{\circ} \mathrm{E}$ covering the Barents Sea opening between Bear Island and $71^{\circ} \mathrm{N}$ was performed. Figure 5a shows that AW essentially fills the entire water column, except for a thin $(50 \mathrm{~m})$ lens of low salinity BSPW [Hopkins, 1991]. Temperatures remain warm $\left(>5^{\circ} \mathrm{C}\right)$ throughout the water column until $\sim 73^{\circ} \mathrm{N}$ (Figure $5 \mathrm{~b}$ ). Farther northward, temperatures reduce rapidly to $\sim 2^{\circ} \mathrm{C}$, from surface to bottom.

\subsection{Velocity Structure and Transports}

[30] In this chapter we present and compare the geostrophic and ADCP derived velocity structure. The meridional transports are derived from the absolute velocity field as it is estimated from the assumption, that the ADCP velocities can serve as a reference for an adjustment of

Table 2b. Water Mass Characteristics of the Fram Strait

\begin{tabular}{lcl}
\hline \multicolumn{1}{c}{ Layer } & Acronym & \multicolumn{1}{c}{ Definitions } \\
\hline Surface & PW & $\Theta<0^{\circ} \mathrm{C} ; S<34.7$ \\
& ASW & $0^{\circ} \mathrm{C}<\Theta<2{ }^{\circ} \mathrm{C} ; S<34.7 ; \Theta>2{ }^{\circ} \mathrm{C} ; S<34.9$ \\
& MAW & $0^{\circ} \mathrm{C}<\Theta<2{ }^{\circ} \mathrm{C} ; 34.4<\Theta<34.9$ \\
Intermediate & AW & $\Theta>3^{\circ} \mathrm{C} ; S>34.9$ \\
& RAW & $\Theta>0^{\circ} \mathrm{C} ; S>34.9$ \\
& UAIW & $\Theta<1^{\circ} \mathrm{C} ; 34.7<S<34.9$ \\
Deep & LAIW & $0^{\circ} \mathrm{C}<\Theta<3{ }^{\circ} \mathrm{C} ; S>34.9$ \\
& UPDW & $-0.5^{\circ} \mathrm{C}<\Theta<0{ }^{\circ} \mathrm{C} ; 34.87<S<34.92$ \\
& CBDW & $-0.8^{\circ} \mathrm{C}<\Theta<-0.5^{\circ} \mathrm{C} ; S>34.92$ \\
& EBDW & $-1.2^{\circ} \mathrm{C}<\Theta<-0.8^{\circ} \mathrm{C} ; S>34.92$ \\
Bottom & DW & $\sigma_{2}<37.457 ;-1.2^{\circ} \mathrm{C}<\Theta<-0.5 ; S<34.92$ \\
\hline
\end{tabular}



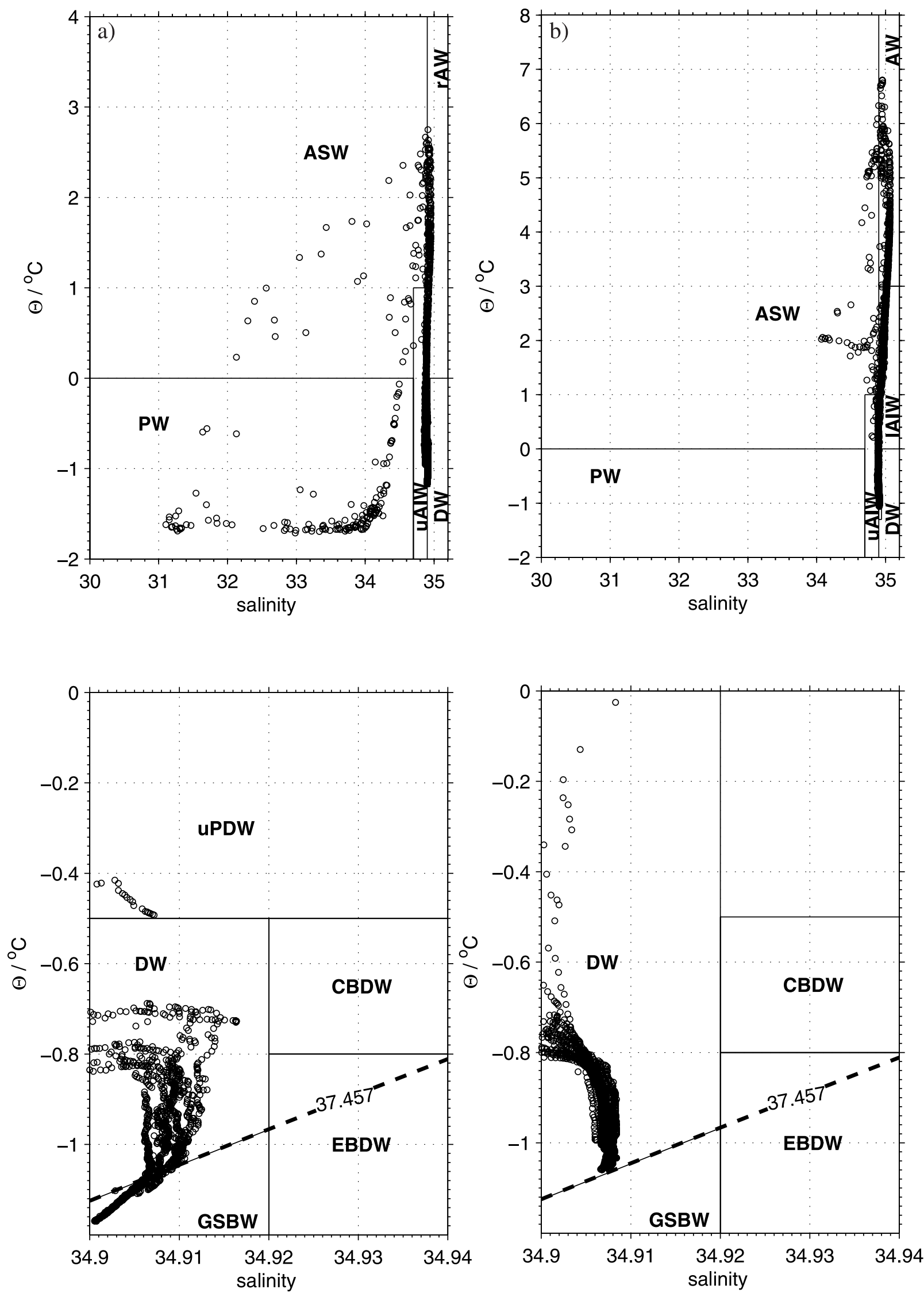

Figure 2. $\Theta / \mathrm{S}$ diagram and water mass definitions for (a) the western periphery and (b) the eastern periphery of the Greenland Sea. Lower panels are $\Theta / \mathrm{S}$ plots on an expanded scale to illustrate the properties of the deep water components. The shown isopycnal is $\sigma_{2}=37.457$. 

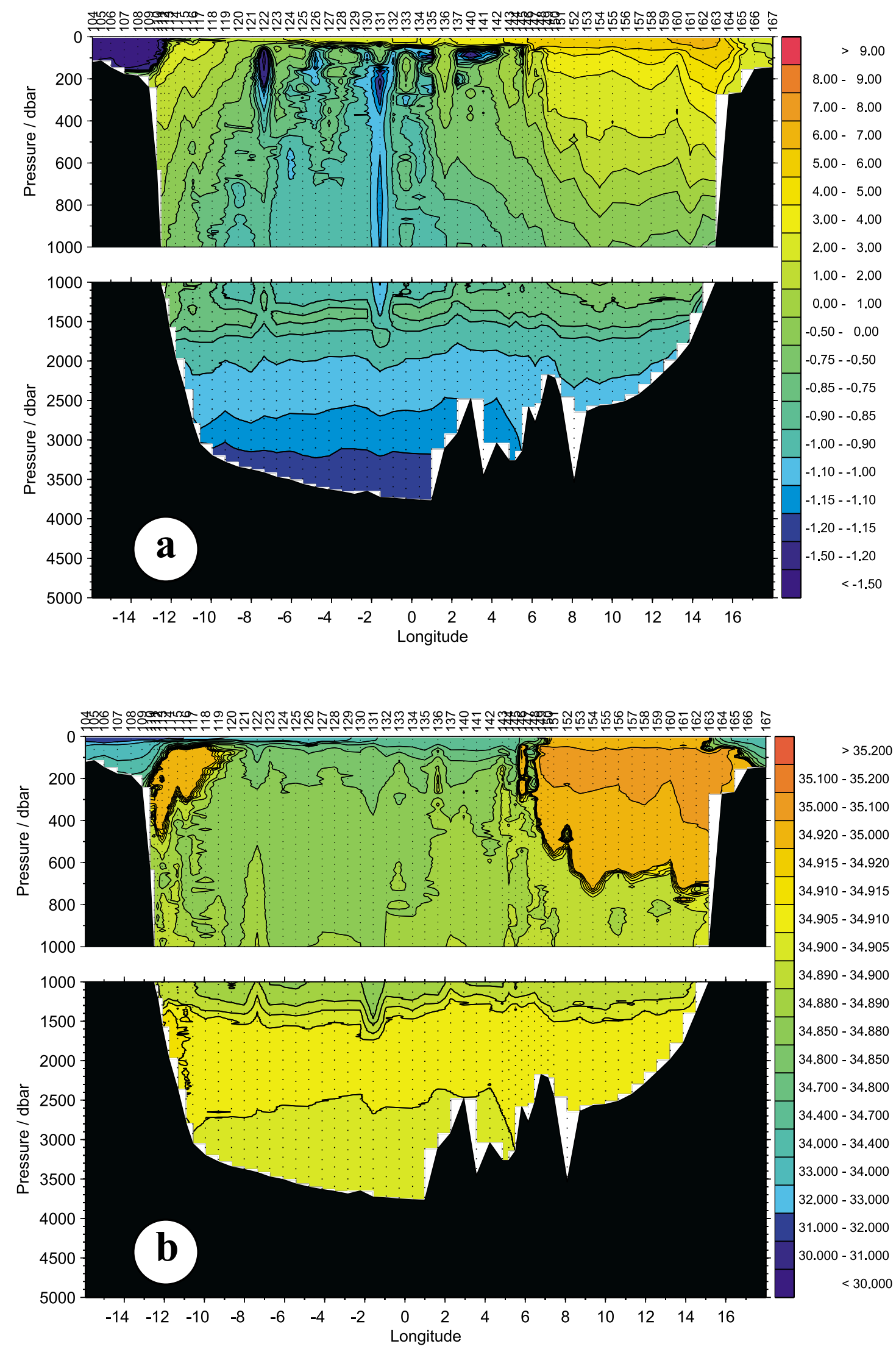

Figure 3. (a) Potential temperature and (b) salinity at $75^{\circ} \mathrm{N}$, Greenland Sea, performed 1997. 

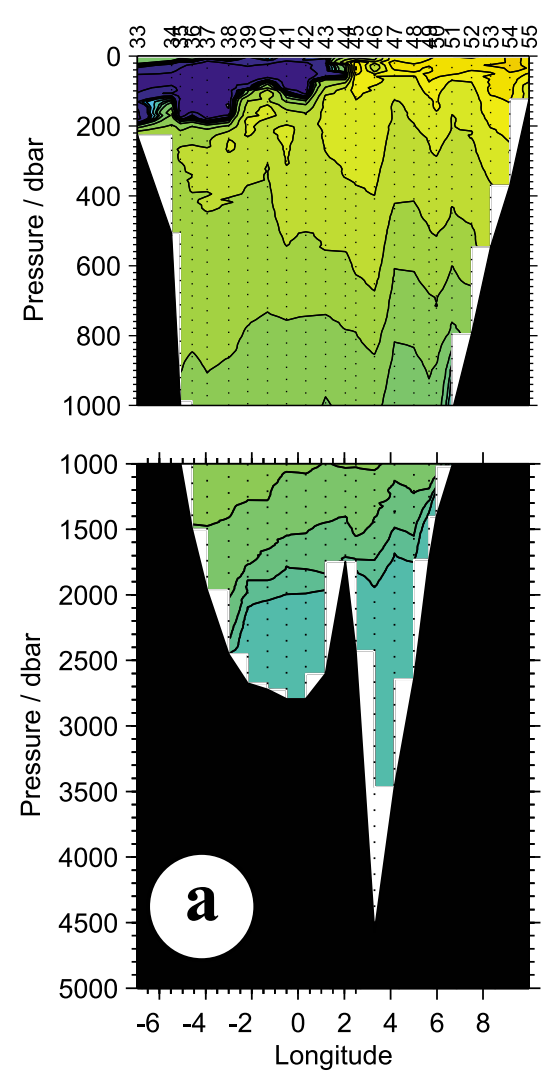
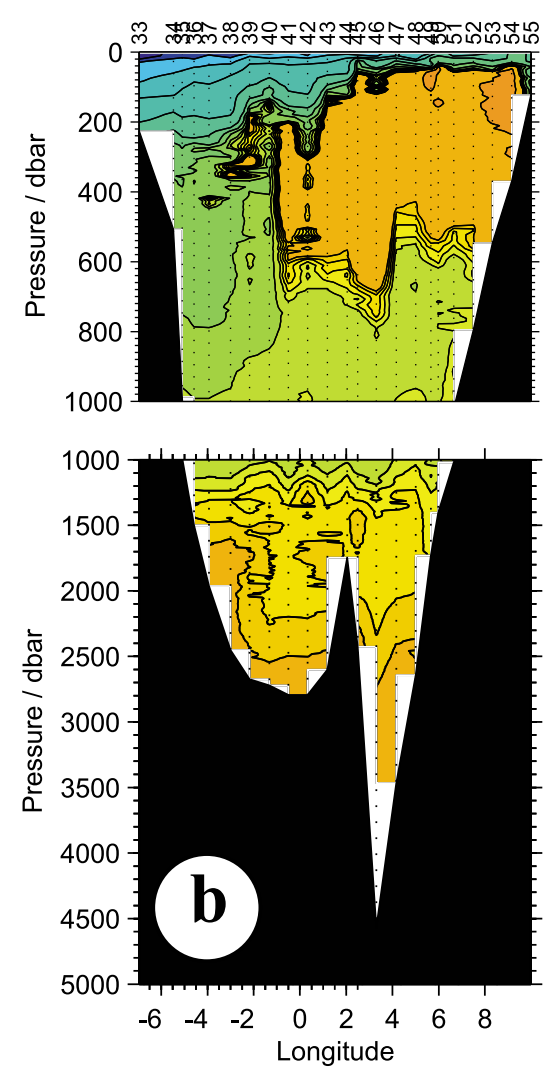

Figure 4. (a) Potential temperature and (b) salinity at $79^{\circ} 40^{\prime} \mathrm{N}$, Fram Strait, performed 1997.

the geostrophic velocities and that geostrophy adequately describes the interior of the deep ocean.

[31] To illustrate the reliability of this referencing technique we present examples with better and lesser similarities of the vertical shear profiles in Figure 6. The profiles b and $c$ taken in the central Greenland Sea and the WSC reveal a good similarity between the vertical current shears of the geostrophic and pair-averaged ADCP profiles in the depth range between 100 and $300 \mathrm{~m}$. The barotropic velocity components are 5 to $10 \mathrm{~cm} \mathrm{~s}^{-1}$. On the other hand, the largest observed deviations between the geostrophic and ADCP derived vertical shear is shown in a and $d$, the fourth example representing current velocities measured on the Barents Sea shelf suggesting that the uppermost 100 and $150 \mathrm{~m}$ are strongly affected by ageostrophic components. More than $90 \%$ of the chosen profiles show a good agreement of the geostrophic shear and the vertical shear of the ADCP profiles.

\subsubsection{Greenland Sea}

[32] To facilitate a comparison between the results presented here and previous estimates we first calculate the cumulative geostrophic volume transport relative to 1000 dbar for the years 1994, 1995, 1997 and 1998. Figure 7a displays the estimated cumulative geostrophic volume transport across these four quasi-synoptic hydrographic sections, which are all performed during summer.

[33] Over the East Greenland shelf, extending from $17^{\circ}-$ $13^{\circ} \mathrm{W}$, weak horizontal density gradients lead to weak transports. Further east, between $13^{\circ}$ and $10^{\circ} \mathrm{W}$, the EGPF induces a strong baroclinic jet over the continental slope with maximum velocities of $\sim 60 \mathrm{~cm} \mathrm{~s}^{-1}$ (1998) near the surface, leading to an EGC transport of $2 \mathrm{~Sv}$. These observations confirm prior results from Paquette et al. [1985]. The EGC shows little interannual variation both in its spatial pattern and transport volumes.
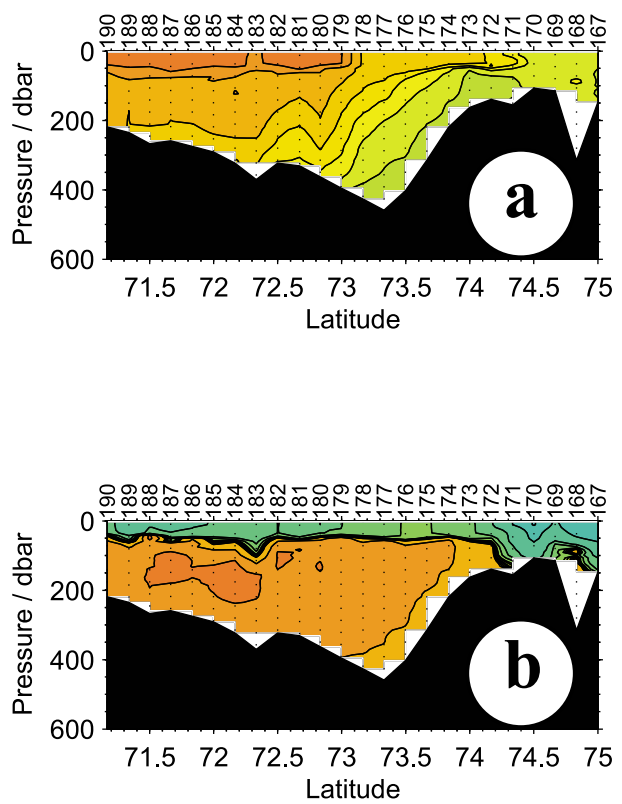

Figure 5. (a) Potential temperature and (b) salinity at $18^{\circ} \mathrm{E}$, Barents Sea shelf, performed 1997. 

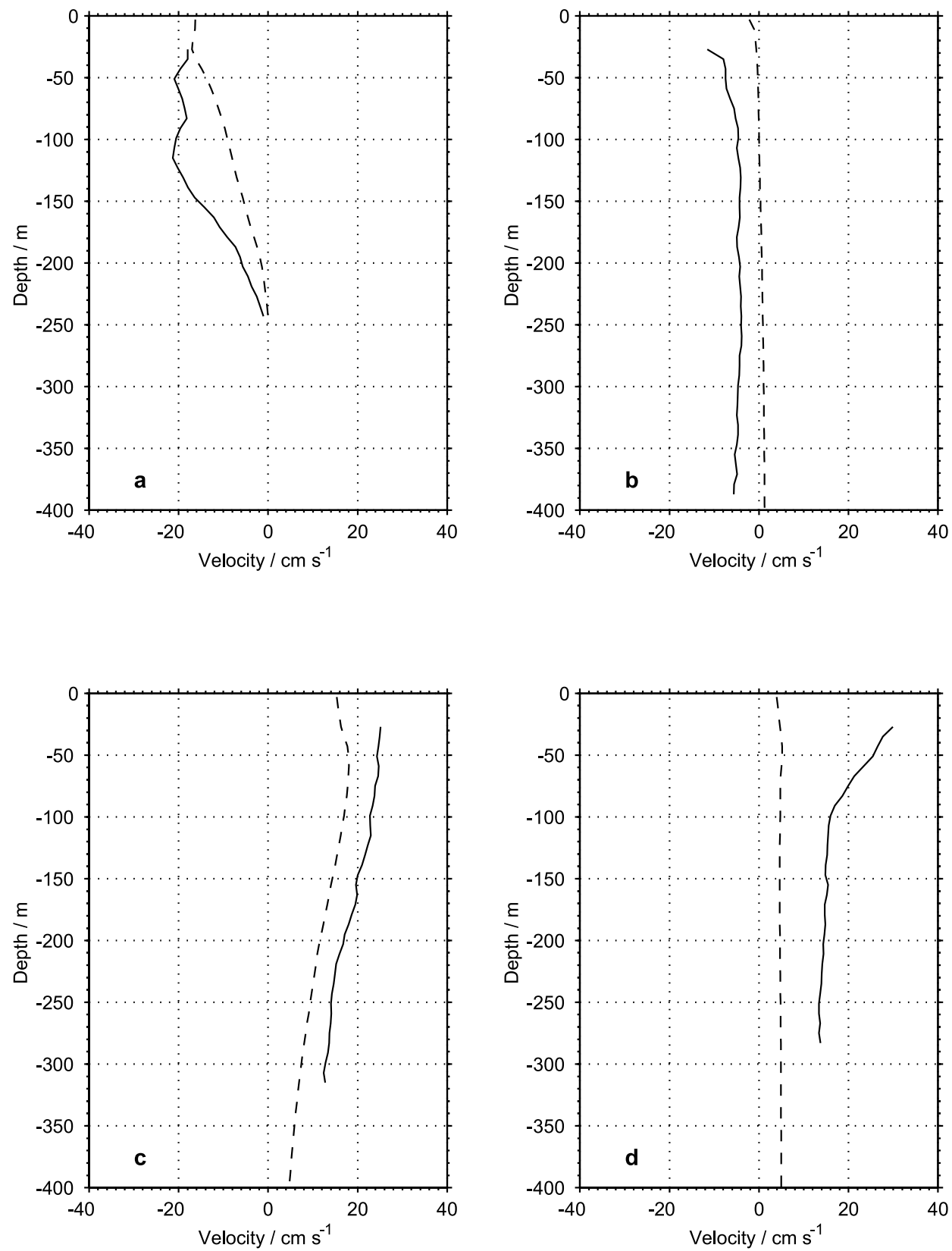

Figure 6. Vertical profiles of geostrophic velocity for the station pairs shown (dashed line) compared to the pair-averaged ADCP profiles (solid line).

[34] Owing to very low horizontal density gradients in the central Greenland Sea no significant change occurs in the cumulative geostrophic volume transport. However, a marked change is seen at the Arctic Front. High-density gradients lead to enhanced northward WSC transports.

[35] In contrast to the EGC the WSC reveals a strong mesoscale and interannual variability. The total baroclinic transports above $1000 \mathrm{~m}$ range between 3 and $6 \mathrm{~Sv}$. The baroclinic AW transports within the WSC $(S>34.9, \theta>3)$ range between 0.7 $\mathrm{Sv}$ (1997) and 3.6 Sv (1995).

[36] It should be noted that all transports are summer values and cannot be used to infer mean annual transports, which are known to exhibit a large seasonal variability [Hill and Lee, 1957; Kislyakov, 1960; Timofeyev, 1962]. The interannual variability of the baroclinic AW transports across $75^{\circ} \mathrm{N}$ is strongly related to the cross-sectional area occupied by this water mass (Figure 7b), so that mean northward velocities of the AW must be similar.

[37] The ADCP measurements in 1997 (averages between station pairs) are depicted as eastward and northward components in Figures 8a and 8b. Note that the vertical range is $400 \mathrm{~m}$ only. It is immediately apparent that the velocity field in the central Greenland Sea exhibits much more structure and generally higher speeds than the geostrophic field shown in Figure 9a, and that it is organized in an essentially columnar pattern. Barotropic constituents are also important in the Polar and Atlantic domain, including the two frontal systems. Using the northward component as a reference for the geostrophic velocity profiles results in a velocity field, which is shown in Figure 9b. 


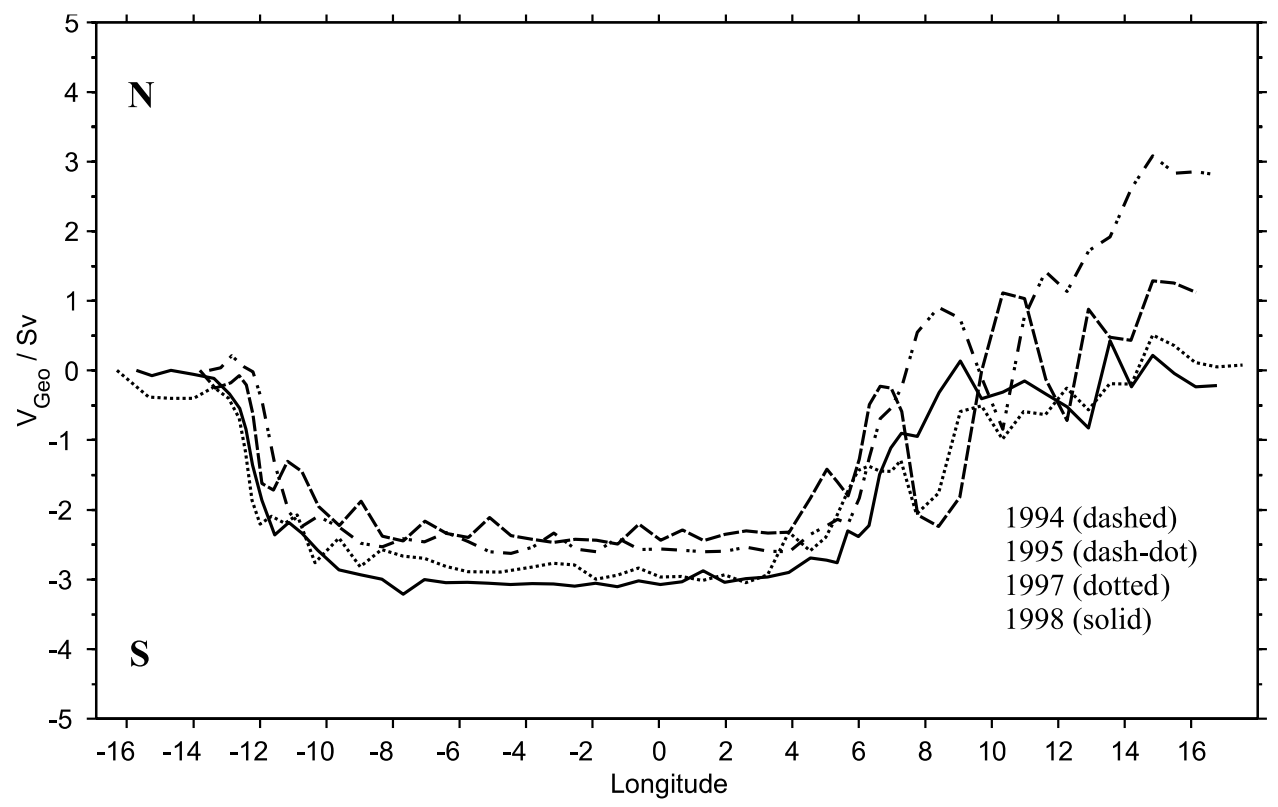

Figure 7a. Cumulative geostrophic transports across $75^{\circ} \mathrm{N}$ relative to $1000 \mathrm{dbar}$.

[38] The magnitude of the adjustments from relative to absolute velocities ranges from -11 to $25 \mathrm{~cm} \mathrm{~s}^{-1}(-11-$ $1 \mathrm{~cm} \mathrm{~s}^{-1}$ in the EGC region). $63 \%$ of the adjustments are in the same direction as the maximum relative current. $34 \%$ are in the opposite direction, mostly occurring in the WSC area.
[39] As in the ADCP measurements, the derived flow field exhibits a columnar structure. A layer of no motion is not apparent. Over the East Greenland continental slope the highest velocities of $49 \mathrm{~cm} \mathrm{~s}^{-1}$ occur near the surface and are associated with the East Greenland Current. At $75^{\circ} \mathrm{N}$ this current is confined to a zone of $\sim 150 \mathrm{~km}$ width. The

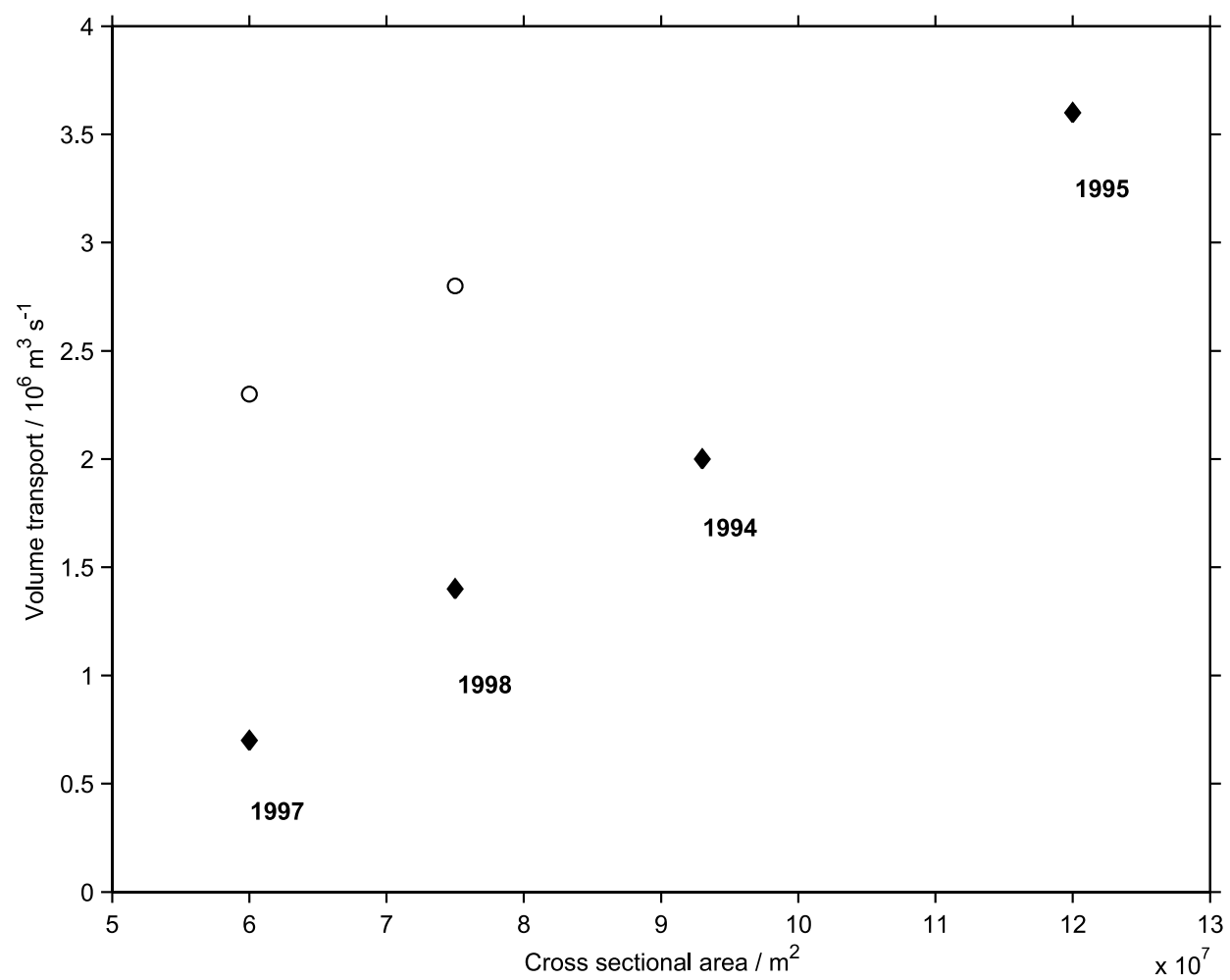

Figure 7b. Geostrophic (diamonds) and absolute (circles) AW transports plotted against the crosssectional area occupied by the AW at $75^{\circ} \mathrm{N}$. 

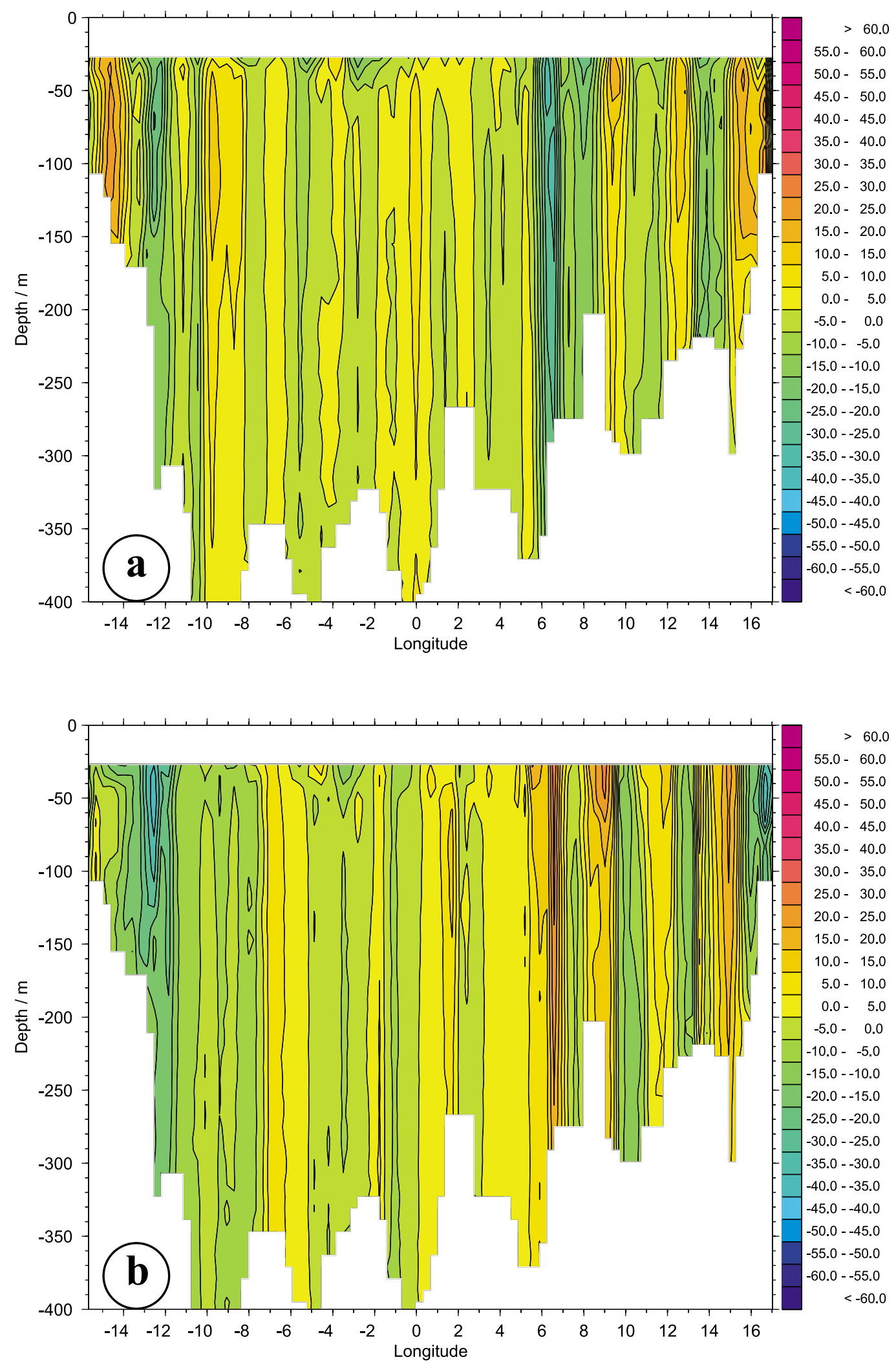

Figure 8. Vertical distributions of (a) east/west and (b) north/south ( \pm ) components of the corrected water velocity from ADCP measurements along the $75^{\circ} \mathrm{N}$ transect in 1997 . 

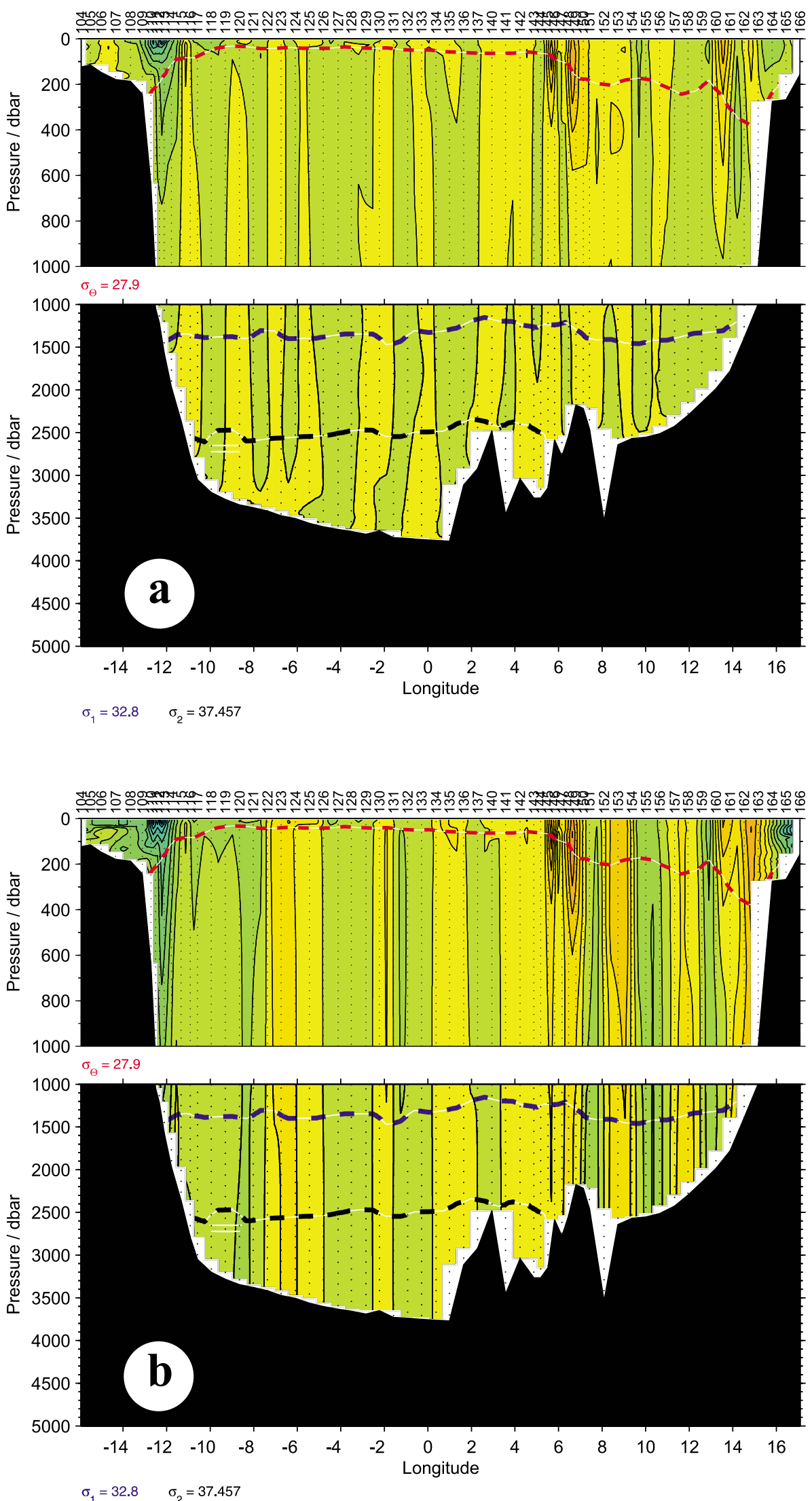

Figure 9. Vertical distributions of the geostrophic velocity along the $75^{\circ} \mathrm{N}$ transect in 1997 relative to (a) a layer of no motion at the bottom and (b) a layer of no motion at the bottom adjusted to the ADCP velocities (northward velocities are positive, layer boundaries are indicated by isopycnals for the transport discussion). 
Table 3a. Regional Distribution of Water Mass Transports Across $75^{\circ} \mathrm{N}(1997)^{\mathrm{a}}$

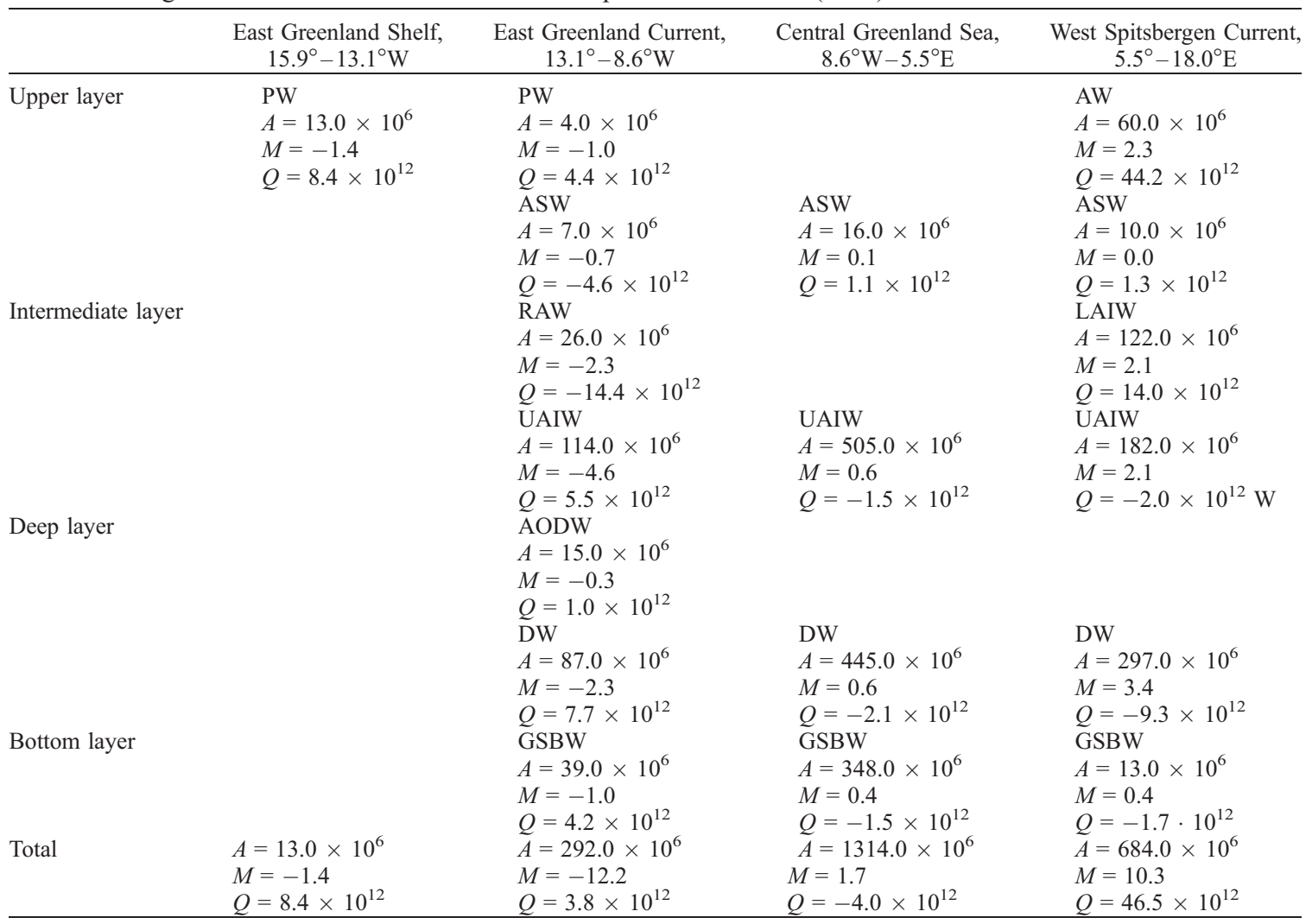

${ }^{\mathrm{a}} A$ is in $\mathrm{m}^{2} ; M$ is in $\mathrm{Sv}$; and $Q$ is in $\mathrm{W}$.

Table 3b. Regional Distribution of Water Mass Transports Across $75^{\circ} \mathrm{N}(1998)^{\mathrm{a}}$

\begin{tabular}{|c|c|c|c|c|}
\hline & $\begin{array}{c}\text { East Greenland Shelf, } \\
16.9^{\circ}-13.1^{\circ} \mathrm{W} \\
\end{array}$ & $\begin{array}{c}\text { East Greenland Current, } \\
13.1^{\circ}-8.0^{\circ} \mathrm{W} \\
\end{array}$ & $\begin{array}{c}\text { Central Greenland Sea, } \\
8.0^{\circ} \mathrm{W}-3.3^{\circ} \mathrm{E} \\
\end{array}$ & $\begin{array}{c}\text { West Spitsbergen Current, } \\
3.3^{\circ}-18.0^{\circ} \mathrm{E} \\
\end{array}$ \\
\hline \multirow[t]{8}{*}{ Upper Layer } & PW & PW & & AW \\
\hline & $A=17.0 \times 10^{6}$ & $A=3.0 \times 10^{6}$ & & $A=75.0 \times 10^{6}$ \\
\hline & $M=-0.2$ & $M=-0.9$ & & $M=2.8$ \\
\hline & $Q=0.7 \times 10^{12}$ & $Q=4.2 \times 10^{12}$ & & $Q=60.8 \times 10^{12}$ \\
\hline & & ÂSW & ASW & ASW \\
\hline & & $A=5.0 \times 10^{6}$ & $A=13.0 \times 10^{6}$ & $A=10.0 \times 10^{6}$ \\
\hline & & $M=-1.0$ & $M=-0.1$ & $M=0.5$ \\
\hline & & $Q=-6.3 \times 10^{12}$ & $Q=-0.2 \times 10^{12}$ & $Q=9.6 \times 10^{12}$ \\
\hline \multirow[t]{8}{*}{ Intermediate layer } & & RAW & & LAIW \\
\hline & & $A=15.0 \times 10^{6}$ & & $A=98.0 \times 10^{6}$ \\
\hline & & $M=-1.8$ & & $M=0.0$ \\
\hline & & $Q=-9.5 \times 10^{12}$ & & $Q=0.4 \times 10^{12}$ \\
\hline & & UAIW & UAIW & UAIW \\
\hline & & $A=146.0 \times 10^{6}$ & $A=433.0 \times 10^{6}$ & $A=267.0 \times 10^{6}$ \\
\hline & & $M=-4.6$ & $M=0.8$ & $M=2.7$ \\
\hline & & $Q=0.7 \times 10^{12}$ & $Q=-5.2 \times 10^{12}$ & $Q=-3.5 \times 10^{12}$ \\
\hline \multirow[t]{7}{*}{ Deep layer } & & AODW & & \\
\hline & & $A=14.0 \times 10^{6}$ & & \\
\hline & & $\begin{aligned} M & =-0.6 \\
Q & =2.0 \times 10^{12}\end{aligned}$ & & \\
\hline & & & DW & \\
\hline & & $A=113.0 \times 10^{6}$ & $A=372.0 \times 10^{6}$ & $A=376.0 \times 10^{6}$ \\
\hline & & $M=-2.5$ & $M=1.8$ & $M=1.5$ \\
\hline & & $Q=7.0 \times 10^{12}$ & $Q=-6.6 \times 10^{12}$ & $Q=-5.8 \times 10^{12}$ \\
\hline \multirow[t]{4}{*}{ Bottom layer } & & GSBW & GSBW & GSBW \\
\hline & & $A=51.0 \times 10^{6}$ & $A=273.0 \times 10^{6}$ & $A=20.0 \times 10^{6}$ \\
\hline & & $M=-0.5$ & $M=1.7$ & $M=0.4$ \\
\hline & & $Q=1.9 \times 10^{12}$ & $Q=-7.4 \times 10^{12}$ & $Q=-1.7 \times 10^{12}$ \\
\hline \multirow[t]{3}{*}{ Total } & $A=17.0 \times 10^{6}$ & $A=347.0 \times 10^{6}$ & $A=1091.0 \times 10^{6}$ & $A=846.0 \times 10^{6}$ \\
\hline & $M=-0.2$ & $M=-11.9$ & $M=4.2$ & $M=7.9$ \\
\hline & $Q=0.7 \times 10^{12}$ & $Q=0.0 \times 10^{12}$ & $Q=-19.4 \times 10^{12}$ & $Q=59.8 \times 10^{12}$ \\
\hline
\end{tabular}

${ }^{\mathrm{a}} A$ is in $\mathrm{m}^{2} ; M$ is in $\mathrm{Sv}$; and $Q$ is in $\mathrm{W}$. 


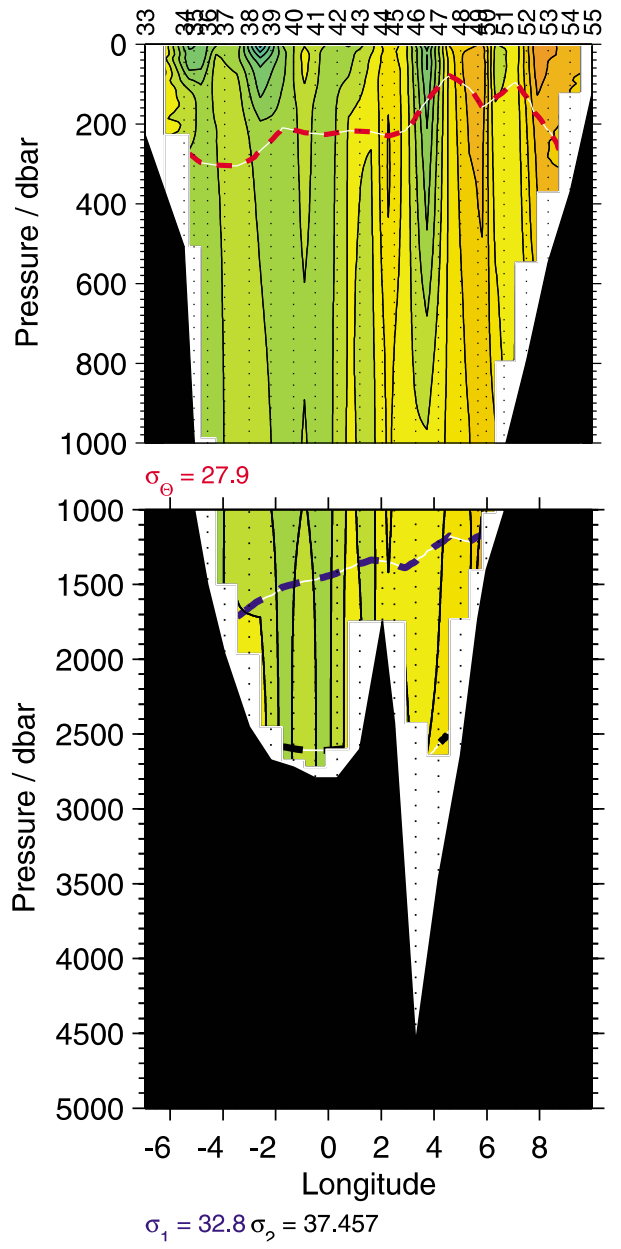

Figure 10. Vertical distributions of the absolute velocity along the $79^{\circ} 40^{\prime} \mathrm{N}$ transect in 1997 (northward velocities are positive, layer boundaries are indicated by isopycnals for the transport discussion).

velocities decrease with depth, indicating that the flow in the upper $1000 \mathrm{~m}$ has a considerable baroclinic component. Striking features of the EGC are the observed bottomintensified velocities over the continental slope $\left(11^{\circ}-\right.$ $\left.12^{\circ} \mathrm{W}\right)$. Similar bottom intensifications have previously been observed by moorings for limited time intervals [Fahrbach et al., 1995; Woodgate et al., 1999] and similar CTD/ADCP surveys covering the Barents Sea shelf break front [Parsons et al., 1996].

[40] Although remotely sensed images [Smith and Bird, 1991], drifters [Gascard et al., 1988] and moored current meters [Foldvik et al., 1988] in the East Greenland Current marginal ice zone further north show a variety of mesoscale motions with spatial scales from several kilometers to $100 \mathrm{~km}$, the velocity field of the EGC does not reveal any significant mesoscale variability at $75^{\circ} \mathrm{N}$, i.e., the flow is nearly unidirectional. The WSC exhibits eddies and broad stream bands leading to a highly mesoscale variability. van Aken et al. [1995] investigated the structure and the properties of the AF by means of expendable bathythermograph (XBT) surveys, CTD sections, surface drifters and ADCP measurements, representing the first direct current measurements in the WSC along $75^{\circ} \mathrm{N}$. They observed on both sides of the front bands of shallow cyclonic cold eddies and anticyclonic warm eddies with horizontal scales of the order of $40-$ $50 \mathrm{~km}$. These results agreed with Rodionov [1992], who detected many different mesoscale and small-scale structures in the Artic Front regions by using IR radiometer measurements. We recognize from the data set evaluated here that eddies and current meanders occur not only in the vicinity to the front but also within the entire WSC. With respect to transport estimates it is clear that due to the high barotropic velocity components in both boundary currents our transports are much higher than the results from geostrophic estimates.

[41] The regional and vertical distributions of individual water mass transports for the $75^{\circ} \mathrm{N}$ transects of 1997 and 1998 are shown in Tables $3 \mathrm{a}$ and $3 \mathrm{~b}$. We divide the transects into four regions (EG Shelf, EGC, central Greenland Sea, and WSC) and four layers. It is immediately apparent from both tables that large volume transports are not confined to the upper layer but are also found in the intermediate and deep layers. In both years, 1997 and 1998, the intermediate layer shows the largest absolute transports (11.7 Sv in 1997, $9.9 \mathrm{~Sv}$ in 1998). The most important individual contribution stems from the UAIW in both years, amounting to twice or more of the RAW value. The importance of the intermediate layer is less pronounced in the WSC than in the EGC. This is partly due to the deeper level of the boundary between upper and intermediate layer in the Atlantic Domain, so that all AW is included in the upper layer. However, equally important is the fact, that the many flow reversions in the WSC lead to transports, which are comparatively small regarding the large areas covered by AW or the waters below. This leads to small average northward velocities in the Atlantic Domain despite the relatively high local speeds.

[42] The mean northward flow is here only 3.8 and $3.7 \mathrm{~cm}$ $\mathrm{s}^{-1}$ (1997 and 1998). A striking feature is that the variability of both the geostrophic and absolute AW transport across $75^{\circ} \mathrm{N}$ is governed by the cross-sectional area occupied by this water mass (Figure 7b). This may lead to the assumption that the AW transport is predictable from its cross-sectional area alone, but due to the short time series this is rather speculative at the moment. Related to the low average velocity of the AW its mean travel time is almost half a year (152 days) for the approximately $500 \mathrm{~km}$ between $75^{\circ} \mathrm{N}$ and $79^{\circ} \mathrm{N}$. Seasonal signals are transported with according time lags.

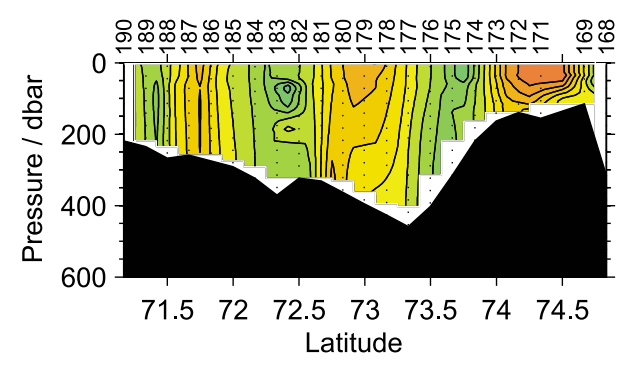

Figure 11. Vertical distributions of the absolute velocity along the $18^{\circ} \mathrm{E}$ transect in 1997 (eastward velocities are positive). 


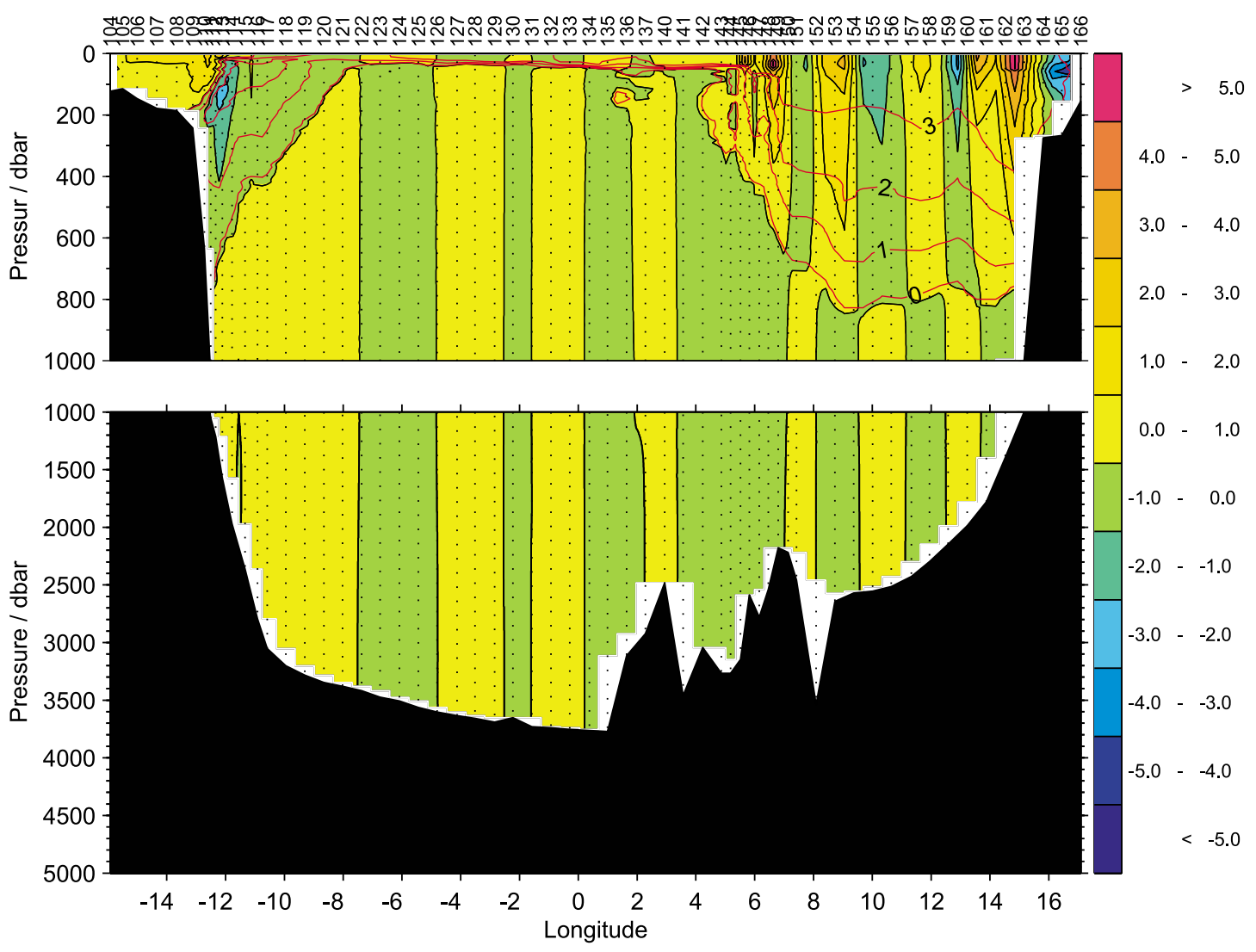

Figure 12. Vertical distributions of the heat flux density along the $75^{\circ} \mathrm{N}$ transect in 1997 (positive heat flux densities indicating northward heat flux; "warm water layer" is indicated by isotherms).

[43] Although PW, RAW, AW, LAIW and ASW encompass relatively small cross sections they provide $\sim 67 \%$ of the total volume transport. Over the East Greenland shelf region the PW transport ranges between $-1.4 \pm 0.1 \mathrm{~Sv}$ (1997) and $-0.2 \pm 0.1 \mathrm{~Sv}$ (1998). Different mean flow rates of 11.0 and $1 \mathrm{~cm} \mathrm{~s}^{-1}$ (1997 and 1998) induce this interannual variability. The net volume transport across the EGC region $\left(13.1^{\circ}-8.8^{\circ} \mathrm{W}\right)$ is $-12.2 \pm 2.9 \mathrm{~Sv}(1997)$ an $-11.9 \pm$ 3.5 Sv (1998). These results are comparable with summer estimates from current meter moorings in the EGC of Fahrbach et al. [1995] and Woodgate et al. [1999] and support their method of extrapolating from the mooring sites into the central Greenland Sea where a pivot point with zero velocity is assumed. They estimated the annual mean transport of the EGC region as $21 \pm 3 \mathrm{~Sv}$, varying from $11 \mathrm{~Sv}$ in summer to $37 \mathrm{~Sv}$ in winter for 1994/1995. Owing to the dominant southward barotropic velocity components all water masses found in this region reveal net southward transports.

[44] In the central part of the Greenland Sea, between $8.6^{\circ} \mathrm{W}$ and $5.5^{\circ} \mathrm{E}$, the total transport is small. The total transport of the WSC region is $10.3 \pm 6.8 \mathrm{~Sv}$ in 1997 and $7.9 \pm 6.8 \mathrm{~Sv}$ in 1998 . High mesoscale variability induced by eddies and meanders leads to the observed transport differences. The northward transport within the WSC is 26.3 and $27 \mathrm{~Sv}$ in 1997 and 1998, while there is change in the southward transport from -16 to $-19.1 \mathrm{~Sv}$. Eddies and meanders with a horizontal width of 20 to $70 \mathrm{~km}$ contribute to the observed interannual variability.

\subsubsection{Fram Strait}

[45] The relation between geostrophic velocities and ADCP results in Fram Strait is similar to that at $75^{\circ} \mathrm{N}$. Therefore only the combined absolute velocity field is shown in Figure 10. The current regimes of the EGC and the WSC are less separated in Fram Strait than at $75^{\circ} \mathrm{N}$. While the EGC can be identified unambiguously over the East Greenland shelf slope by the maximum southward velocities of $30 \mathrm{~cm} \mathrm{~s}^{-1}$ and a characteristic baroclinic contribution, the WSC shows, similar to the situation at $75^{\circ} \mathrm{N}$, numerous flow reversals but, dissimilar to $75^{\circ} \mathrm{N}$, no zone of small velocities at its western limit. Northward flowing high-saline waters of the WSC are found in the entire region between Spitsbergen and $1^{\circ} \mathrm{E}$ (Station 42) and are not organized in a well-defined stream. The eddies or meanders, spatially resolved by the sampling pattern, show typical length scales of $\sim 40 \mathrm{~km}$. This again is similar to the observations at $75^{\circ} \mathrm{N}$. Five velocity bands can be clearly distinguished between Spitsbergen and the zero meridian.

[46] Along the entire section the magnitude of the adjustments from relative to absolute velocities ranges from -9 to $18 \mathrm{~cm} \mathrm{~s}^{-1}$. With a somewhat deliberate partition at $2^{\circ} \mathrm{E}$, the southward transport in the western part of Fram Strait amounts to $-13.1 \mathrm{~Sv}$ and the eastern part shows a northward transport of $11.5 \mathrm{~Sv}$. In contrast to $75^{\circ} \mathrm{N}$, the deep layers show similar (eastern part) or larger (western part) transport magnitudes than the intermediate layers. 

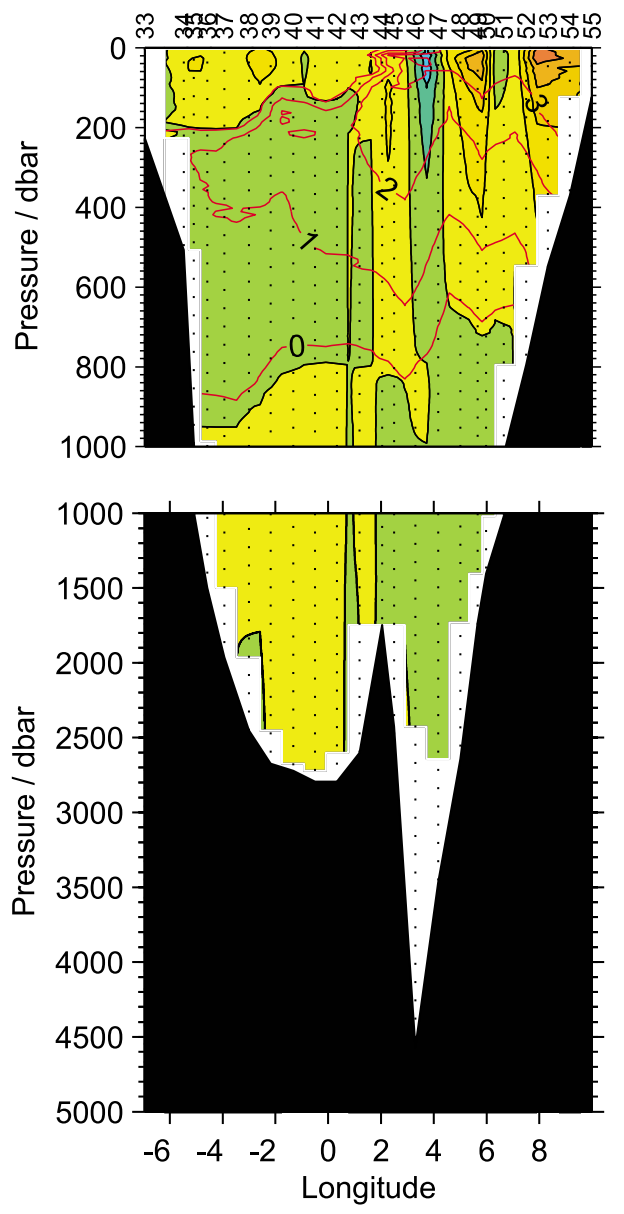

Figure 13. Vertical distributions of the heat flux density along the $79^{\circ} 40^{\prime} \mathrm{N}$ transect in 1997 (positive heat flux densities indicating northward heat flux; "warm water layer" is indicated by isotherms).

\subsubsection{Barents Sea Opening}

[47] The geostrophic velocities along the Bear Island transect are small leading to an eastward geostrophic transport across $18^{\circ} \mathrm{E}$ of $1.4 \mathrm{~Sv}$. This value is comparable to the summer results of Timofeyev [1963] (depicted from Hopkins [1991]) and Druet and Jankowski [1991]. On the basis of 131 hydrographic stations obtained between 1930 and 1961 Timofeyev estimated the yearly mean transport across a section performed between Bear Island and the North Cape of Norway as $\sim 1.6 \mathrm{~Sv}$, varying from $1.2 \mathrm{~Sv}$ in June and 2.0 Sv in November.

[48] However, the absolute velocity field (Figure 11) reveals strong currents with speeds exceeding $60 \mathrm{~cm} \mathrm{~s}^{-1}$. For the $18^{\circ} \mathrm{E}$ transect we calculated the barotropic velocity component by comparing the geostrophic profile with the east/west component of the ADCP velocity. Obviously, the time varying barotropic velocities show a sinusoidal curve, which corresponds to 3 tidal cycles with maximum amplitudes of $15-20 \mathrm{~cm} \mathrm{~s}^{-1}$. The mean velocity field is dominated by semidiurnal tides with amplitude of $\sim 15-20 \mathrm{~cm} \mathrm{~s}^{-1}$ corroborating the results from Kowalik and Proshutinsky [1995] showing that the semidiurnal tide M2 dominates the current regime in the vicinity of Bear Island with amplitudes of the same order. Between 1997 and 1998 Ingvaldsen et al. [2002] deployed an array of five current meter moorings across the Barents Sea Opening between $71^{\circ} 15^{\prime} \mathrm{N}$ and $73^{\circ} 45^{\prime} \mathrm{N}$. The observed current was predominantly barotropic. The volume transport across this section was calculated and gave a net inflow of AW of 2 Sv. However, on a monthly basis, the calculated transport fluctuated over a range of almost $10 \mathrm{~Sv}$.

[49] Compared to the high transport fluctuations observed by Ingvaldsen et al. [2002], our "snapshot" estimates using ADCP-derived velocities results in 1.6 Sv. The time span over which this result is gained has been adjusted to correspond to three tidal cycles.

[50] Nevertheless, local differences in tidal currents may, of course, introduce some bias, but since the transport estimate is of reasonable magnitude we use our data to take advantage of the fact that the hydrographic parameters are measured simultaneously so that the combination of velocities and temperature data on the same grid leads to a consistent heat transport.

\subsection{Heat Fluxes}

[51] While the chosen reference temperature of $-0.1^{\circ} \mathrm{C}$ is not important for the total heat transport over a mass balanced boundary, it does affect the heat flux densities and the heat transports associated with the individual water masses. The heat flux densities across $75^{\circ} \mathrm{N}$ are shown in Figure 12.

[52] In contrast to the volume transports, the predominant heat fluxes are confined to a few hundred $\mathrm{m}$ below the surface because the warmest as well the coldest waters are located in the upper layer of the water column. Consequently, the AW within the WSC contributes most to the heat transport. It ranges between 44.2 TW (1997) and 60.8 TW (1998) (see Tables 3a and 3b). The difference is, as for the volume transport, mainly governed by its cross-sectional area. According to the flow reversals, areas with positive and negative sign alternate in the WSC. Similar relations between heat transport and cross-sectional area can also be seen for the positive Polar Water and negative Return Atlantic Water contributions within the EGC yielding 4.4 and -14.4 TW for 1997 and 4.2 and -9.5 TW for 1998.

[53] The entire central Greenland Sea contributes little to the heat flux due to the small velocities and temperatures close to the reference point. At $79^{\circ} 40^{\prime} \mathrm{N}$ (Figure 13) the only remarkable negative contribution is found at $4^{\circ} \mathrm{E}$, i.e., well inside the area where waters of Atlantic origin are observed. This feature is related to a flow reversal and is probably a small core or filament of RAW. Both Bourke et al. [1988] and Manley [1995] report the presence of RAW at this latitude. The PW again provides a positive contribution.

[54] Previous heat transport estimates from measurements concentrate on the WSC in Fram Strait because of the accessibility and the assumption that heat of the inflowing AW there is available for the Arctic Ocean. Reported values range from $18 \mathrm{TW}$ [Mosby, 1962] to $128 \mathrm{TW}$ [Zaitsev et al., 1961; after Hanzlick, 1983], and the analysis of Hanzlick [1983] gave a variability between -8 TW in March 1977 and 128 TW in December 1976 (two week averages) which is closely related to volume flow changes. With the current pattern and the heat flux density distribution it is clear that the eddy-spiked flow in the WSC poses a severe problem to field derived estimates. 


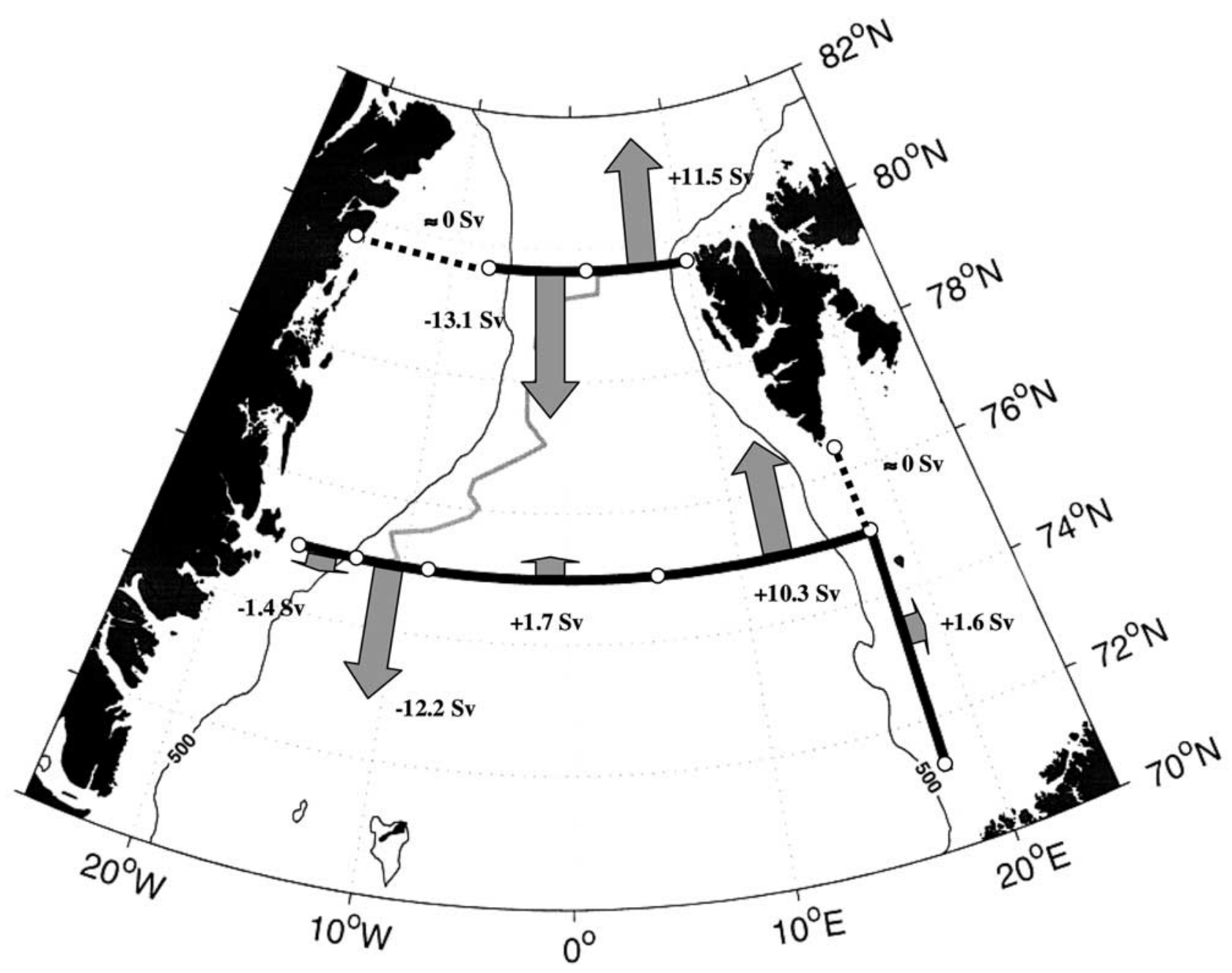

Figure 14a. Volume transports for subregions across the transects. The boundaries of the individual regions are marked by dots.

[55] Before estimating the heat budgets from our measurements two further assumptions have to be made to construct a mass balanced transect system for 1997, which allows for a total heat budget that is independent of the chosen reference temperature. Our boundaries include two gaps which are illustrated together with the regional volume transports as dashed lines in Figure 14a, and across which we assume vanishing transports. Timofeyev [1963] estimated the monthly geostrophic transport rates across the South Cape/Bear Island section. The transports for the summer months ranged between 0.2 and $0.3 \mathrm{~Sv}$ thus corroborating our assumption. The gap across the East Greenland Shelf along the $79^{\circ} 40^{\prime} \mathrm{N}$ is closed using results of Bourke et al. [1987] and Schneider and Budéus [1995]. Both identified an anticyclonic eddy over the shelf area with a mass balance close to zero. Consequently, we can regard the transect combination as two transects over which the net volume flow is zero. The resulting mass and heat transports for specific water masses are compiled in Tables $3 \mathrm{a}$ and $3 \mathrm{c}$, where the values for both $75^{\circ} \mathrm{N}$ and $79^{\circ} 40^{\prime} \mathrm{N}$ are included.
[56] We see that at $75^{\circ} \mathrm{N}$ the AW contributes most to the heat transport. The importance of the AW transport is emphasized by the fact that its value of $44.2 \mathrm{TW}$ is close to that of the net heat exchange of $54.7 \mathrm{TW}$ across the entire transect.

[57] Another important contribution is provided by the PW, which balances that of the RAW. A further remarkable amount is supplied by the LAIW (flowing below the AW). The sum of this together with that of the AW, $58.2 \mathrm{TW}$, is close to those the WSC estimate by Aagaard and Greisman [1975] of $68 \mathrm{TW}$, but on its way from $75^{\circ} \mathrm{N}$ to Fram Strait the AW looses a major amount of its heat content and at $79^{\circ} 40^{\prime} \mathrm{N}$ only 17 TW enter the Arctic Ocean with the AW. Much of the former AW falls now into the category of LAIW, and their sum provides only $40 \mathrm{TW}$. This is a comparatively low figure despite the fact that our volume transports exceed the cited literature. At $79^{\circ} 40^{\prime} \mathrm{N}$ the $\mathrm{PW}$ heat transport approximately resembles that at $75^{\circ} \mathrm{N}(12.8 \mathrm{TW})$. Since RAW and LAIW are not regionally separated in Fram Strait, only their combined contribution can be given (13.2 TW), which is possibly 
Table 3c. Regional Distribution of Water Mass Transports Across $79^{\circ} 40^{\prime} \mathrm{N}(1997)^{\mathrm{a}}$

\begin{tabular}{|c|c|c|}
\hline & $\begin{array}{c}\text { Western Fram Strait, } \\
7.0^{\circ}-2.0^{\circ} \mathrm{W}\end{array}$ & $\begin{array}{c}\text { Eastern Fram Strait, } \\
2.0^{\circ} \mathrm{E}-10.0^{\circ} \mathrm{W}\end{array}$ \\
\hline Upper layer & $\begin{array}{l}\text { PW } \\
A=27.0 \times 10^{6} \\
M=-1.6 \\
Q=7.8 \times 10^{12}\end{array}$ & $\begin{array}{l}\text { ASW } \\
A=9.0 \times 10^{6} \\
M=0.7 \\
Q=13.0 \times 10^{12} \\
\text { AW } \\
A=8.0 \times 10^{6} \\
M=1.1 \\
Q=16.7 \times 10^{12}\end{array}$ \\
\hline Intermediate layer & $\begin{array}{l}\text { MAW } \\
A=62.0 \times 10^{6} \\
M=-3.3 \\
Q=-10.4 \times 10^{12} \\
\text { RAW } \\
A=34.0 \times 10^{6} \\
M=-1.1 \\
Q=-6.6 \times 10^{12}\end{array}$ & $\begin{array}{l}\text { LAIW } \\
A=71.0 \times 10^{6} \\
M=3.0 \\
Q=23.6 \times 10^{12} \\
\text { UAIW } \\
A=36.0 \times 10^{6} \\
M=1.8 \\
Q=-1.5 \times 10^{12}\end{array}$ \\
\hline \multirow[t]{2}{*}{ Deep layer } & $\begin{array}{l}\text { UPDW } \\
A=57.0 \times 10^{6} \\
M=-2.5 \\
Q=1.8 \times 10^{12} \\
\mathrm{CBDW} \\
A=10.0 \times 10^{6} \\
M \approx 0 \\
Q \approx 0 \times 10^{12}\end{array}$ & \\
\hline & $\begin{array}{l}\text { DW } \\
A=121.0 \times 10^{6} \\
M=-4.0 \\
Q=11.0 \times 10^{12}\end{array}$ & $\begin{array}{l}\text { DW } \\
A=91.0 \times 10^{6} \\
M=3.9 \\
Q=-11.8 \times 10^{12}\end{array}$ \\
\hline Bottom layer & $\begin{aligned} A & =16.0 \times 10^{6} \\
M & =-0.6 \\
Q & =2.0 \times 10^{12}\end{aligned}$ & $\begin{array}{l}\text { EBDW } \\
A=20.0 \times 10^{6} \\
M=1.0 \\
Q=-3.6 \times 10^{12}\end{array}$ \\
\hline Total & $\begin{array}{l}A=327.0 \times 10^{6} \\
M=-13.1 \\
Q=5.6 \times 10^{12}\end{array}$ & $\begin{array}{l}A=235.0 \times 10^{6} \\
M=11.5 \\
Q=36.4 \times 10^{12}\end{array}$ \\
\hline
\end{tabular}

${ }^{\mathrm{a}} A$ is in $\mathrm{m}^{2} ; M$ is in $\mathrm{Sv}$; and $Q$ is in $\mathrm{W}$.

somewhat higher than at $75^{\circ} \mathrm{N}(4 \mathrm{TW})$ because some AW has been transformed by cooling to LAIW. The estimate for PW closely resembles that of Aagaard and Greisman [1975] (8 TW) while the $0.03 \mathrm{~Sv}$ attributed to the PW by Mauritzen [1994] would lead to an unrealistic and negligible heat flux.The transect integrated heat transports amount to 54.7 TW for $75^{\circ} \mathrm{N}, 42.0 \mathrm{TW}$ for $79^{\circ} 40^{\prime} \mathrm{N}$, and $31.4 \mathrm{TW}$ for $18^{\circ} \mathrm{E}$.

[58] The latter seems to be largely at odds with the Aagaard and Greisman [1975] estimate, but it has to be considered that our measurements are performed at the entrance and not at the northern boundary of the Barents Shelf. Even with the moderate heat loss to the atmosphere of $25 \mathrm{~W} \mathrm{~m}^{-2}$ [Mauritzen, 1994] there remains only a marginal heat input to the Arctic by the Barents Shelf branch of the AW as is assumed by Aagaard and Greisman [1975]. However, our volume input exceeds their estimate.

[59] The difference between the two zonal transects is a measure of heat loss to the atmosphere between $75^{\circ} \mathrm{N}$ and $80^{\circ} \mathrm{N}$. When distributing the estimated heat loss of $12.7 \times$ $10^{12} \mathrm{~W}$ evenly over the area of $2.5 \times 10^{11} \mathrm{~m}^{2}$ (ice free area, compare Figure $14 \mathrm{~b}$ ), a mean of $51 \mathrm{~W} \mathrm{~m}^{-2}$ results. It is evident that in reality most of the heat loss occurs in the Atlantic domain, which covers at most half $\left(1.25 \times 10^{11} \mathrm{~m}^{2}\right)$ of the mentioned area. Considering further that we measured during summer, our results of $102 \mathrm{~W} \mathrm{~m}^{-2}$ rather support the higher yearly average of $120 \mathrm{~W} \mathrm{~m}^{-2}$ given by Gorshkov [1983] than a value around $70 \mathrm{~W} \mathrm{~m}^{-2}$ as estimated by Mauritzen [1994] for the Atlantic Waters.

[60] Assuming that the contribution over the Barents Shelf is absorbed by the atmosphere, the Fram Strait part of roughly $40 \mathrm{TW}$ represents the heat that does enter the Arctic Ocean. This is considerably less than the 1975 estimate by Aagaard and Greisman [1975] (108 TW), even when taking into account that their value includes the heat transport by ice. Without this, still $84 \mathrm{TW}$ remain, which is twice our result. This is especially remarkable in the context of Arctic warming attributed to enhanced AW inflow [Carmack et al., 1997; Swift et al., 1997].

\section{Conclusions}

[61] Our present knowledge about the northward and southward water mass transports through the Greenland Sea and Fram Strait is essentially based on current meter moorings, geostrophic calculations from hydrographic measurements, and a variety of drifters. In order to explore transports, which account for the spatial velocity structure horizontally on scales of eddies larger than $10-20 \mathrm{~km}$ and vertically in the order of $10 \mathrm{~m}$; we have used a shipmounted ADCP.

[62] These measurements provide "snapshots" of the velocity field on scales normally not resolved and serve as a reference for the conversion of geostrophic velocities with high spatial resolution into absolute velocities. In combination with water mass properties it is possible to calculate the individual transports of characteristic water masses for the whole water column. The combination of high-resolution hydrographic and velocity measurements at identical grid points avoids interpolation problems.

[63] The circulation and transport characteristics of the northern Greenland Sea and the Fram Strait were deduced from three transects, which are regarded as box boundaries and performed during summer 1997. The mass and heat budgets of an area limited to the north and the south by the transects and by the East Greenland and the western Svalbard shelf are presented.

[64] Although all presented measurements bear the character of a snapshot during summer, a number of generally valid conclusions about transport schemes and flux characteristics can be drawn. An important result is that due to the high barotropic component observed both in the EGC and in the WSC, we find significant velocities from surface to bottom. This leads to a consistent cyclonic large-scale circulation at all depth levels without a level of no motion.

[65] The idea of a change of the rotational direction at medium depth as proposed by Koltermann [1991] cannot be corroborated by our data. The importance of the barotropic flow component is also stressed by the comparison between the baroclinic and the barotropic EGC transports. During four years the figures for the baroclinic summer transports amount to roughly $2.5 \mathrm{~Sv}$, while the ADCP-adjusted velocity field reveals more than $10 \mathrm{~Sv}$ both for 1997 and 1998 $\left(75^{\circ} \mathrm{N}\right)$. In this context, the term 'EGC' is related to the area west of $8^{\circ} \mathrm{W}$ at $75^{\circ} \mathrm{N}$, and does not include waters east of this limit. Similarly, the barotropic components of the WSC 


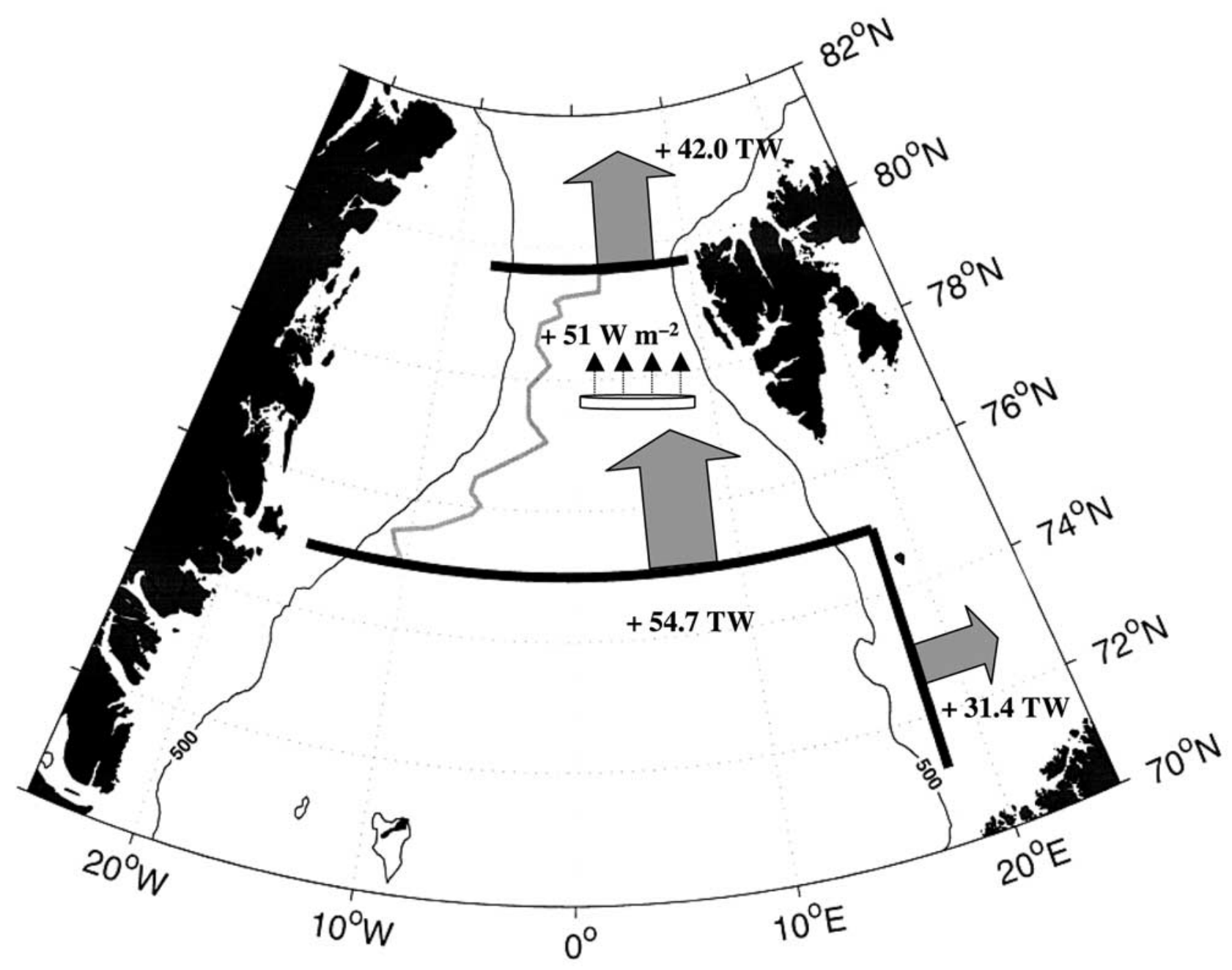

Figure 14b. Heat transport scheme (1997).

volume transports contribute to the fact that our estimate exceeds previous values.

[66] It is remarkable that this is not true for the heat transport, and the most notable figure is the net heat gain of the Arctic, for which our data reveal only 40 TW. In contrast to the volume transports, most of the heat transports occur in the uppermost few hundred $\mathrm{m}$ because of the larger deviation from the reference temperature there.

[67] The structure of the major flow systems is another item of interest. Despite some low speed flow reversals in the eastern vicinity of the EGC, the contrast between this and the WSC is very pronounced. During all our observations the EGC shows a clear and concentrated core of high velocities without return flows of similar speeds. Opposed to this, the WSC is seeded with eddies of some $10 \mathrm{~km}$ radius, and northward and southward speeds are of comparable magnitude. Since these eddies occur not only at the Arctic Front but over the entire width of the Atlantic Domain, the transfer time from $75^{\circ} \mathrm{N}$ to $80^{\circ} \mathrm{N}$ is high ( 200 days) and the atmospheric cooling is correspondingly effective. Naturally, these eddies pose severe problems for a routine estimation of volume and heat transports of the WSC.

[68] The water mass specific transports reveal a very detailed systematic approach, showing that multi year measurements are necessary for the investigation of interannual variations and their causes.

[69] Acknowledgment. This work was partly funded by the EU within project ESOP-2 through contract MAS3-CT95-0015.

\section{References}

Aagaard, K., and P. Greisman, Toward new mass and heat budgets for the Arctic Ocean, J. Geophys. Res., 80, 3821-3827, 1975.

Aagaard, K., J. H. Swift, and E. C. Carmack, Thermohaline circulation in the Arctic Mediterranean Seas, J. Geophys. Res., 90, 4833-4846, 1985.

Alekseev, A. P., and B. V. Istoshin, Some results of oceanographic investigations in the Norwegian and Greenland Seas, in Soviet Fisheries Investigations in the Northern European Seas, pp. 23-36, Polar Res. Inst. of Mar. Fish. and Oceanogr., Moscow, 1960.

Bourke, R. H., J. L. Newton, R. G. Paquette, and M. D. Tunnicliffe, Circulation and water masses of the East Greenland Shelf, J. Geophys. Res., 92, 6729-6740, 1987.

Bourke, R. H., A. M. Weigel, and R. G. Paquette, The westward turning branch of the West Spitsbergen Current, J. Geophys. Res., 93, 14,06514,077, 1988.

Budéus, G., and W. Schneider, In situ temperature calibration: A remark on instruments and methods, WOCE Newsl., 30, 16-18, 1998.

Budéus, G., A.-A. Maul, and G. Krause, Variability in the Greenland Sea as revealed by a repeated high spatial resolution conductivity-temperaturedepth survey, J. Geophys. Res., 102, 9985-10,000, 1993.

Carmack, E. C., On the hydrography of the Greenland Sea, Ph.D. thesis, Univ. of Wash., Seattle, 1972. 
Carmack, E. C., and K. Aagaard, On the deep water of the Greenland Sea, Deep Sea Res., 20, 687-715, 1973.

Carmack, E. C., K. Aagaard, J. H. Swift, R. W. MacDonald, F. A McLaughlin, E. P. Jones, R. G. Perkin, J. N. Smith, K. M. Ellis, and L. R. Killius, Changes in temperature and tracer distributions within the Arctic Ocean: Results from the Arctic Ocean section, Deep Sea Res., 44, $1487-1502,1997$.

Cisewski, B., The transport of heat, mass and salt into the Arctic Ocean, Rep. Polar Mar. Sci., 378, 1-184, 2001.

Druet, C., and A. Jankowski, Flow across south and east boundaries of the Norwegian Sea, Oceanologia, 30, 37-46, 1991

Fahrbach, E., C. Heinze, G. Rohardt, and R. A. Woodgate, Moored current meter measurements in the East Greenland Current, in Nordic Seas Symposium on the Results of the Greenland Sea Project (GSP) 1987-1993, Extended Abstracts, edited by J. Meincke, pp. 57-60, Inst. für Meereskunde, Hamburg, Germany, 1995.

Fahrbach, E., J. Meincke, S. Østerhus, G. Rohardt, U. Schauer, V. Tverberg, and J. Verduin, Direct measurements of volume transports through Fram Strait, Polar Res., 20, 217-224, 2001.

Foldvik, A., K. Aagaard, and T. Tørresen, On the velocity field of the East Greenland Current, Deep Sea Res., 35, 1335-1354, 1988.

Gascard, J.-C., C. Kergomard, P.-F. Jeannin, and M. Fily, Diagnostic study of the Fram Strait marginal ice zone during summer from MINEX 83 and 84 Lagrangian observations, J. Geophys. Res., 93, 3613-3641, 1988.

Gascard, J.-C., A. J. Watson, M. J. Messias, K. A. Olsson, T. Johannessen, and $\mathrm{K}$. Simonsen, Long-lived vortices as a mode of deep ventilation in the Greenland Sea, Nature, 416, 525-527, 2002.

Gorshkov, S. E., World Ocean Atlas 1983, vol. 3, Arctic Ocean, Pergamon, New York, 1983.

Greisman, P. E., Current measurements in the Eastern Greenland Sea, Ph.D. Thesis, Univ. of Wash., Seattle, 1976.

Hanzlick, D. J., The West Spitsbergen Current: Transport, forcing and variability, Ph.D. thesis, Univ. of Wash., Seattle, 1983.

Helland-Hansen, B., and F. Nansen, The Norwegian Sea, 390 pp., Rep. on Norw. Fish. and Mar. Invest., Christiana, Norway, 1909.

Hill, H. W., and A. J. Lee, The effect of the wind on water transport in the region of the Bear Island fisheries, Proc. R. Soc. London, Ser. B, 148, $104-116,1957$

Hopkins, T. S., The GIN Sea-A synthesis of its physical oceanography and literature review 1972-1985, Earth Sci. Rev., 30, 175-319, 1991.

Ingvaldsen, R., H. Loeng, and L. Asplin, Variability in the Atlantic inflow to the Barents Sea based on one-year time series from moored current meters, Cont. Shelf Res., 22, 505-519, 2002.

Joyce, T. M., On in situ calibration of shipboard ADCPs, J. Atmos. Oceanic Technol., 6, 169-172, 1989.

Kislyakov, A. G., Fluctuations in the regime of the Spitsbergen Current, in Soviet Fisheries Investigations in the Northern European Seas, pp. 3949, Polar Res. Inst. of Mar. Fish. and Oceanogr., Moscow, 1960.

Koltermann, K. P., The deep circulation of the Greenland Sea as a consequence of the thermohaline system of the European Polar Seas, Dtsch Hydrogr. Z. Ergänzungsheft, 23, 1-181, 1991.

Kowalik, Z., and A. Y. Proshutinky, Topographic enhancement of tidal motion in the western Barents Sea, J. Geophys. Res., 100, 2613-2637, 1995.

Manley, T. O., Branching of Atlantic Water within the Greenland-Spitsbergen Passage: An estimation of recirculation, J. Geophys. Res., 100 20,627-20,634, 1995 .
Mauritzen, C., A study of the large scale circulation and water mass formation in the Nordic Seas and Arctic Ocean, Ph.D. thesis, Woods Hole Oceanogr. Inst., Mass. Inst. of Technol., Cambridge, 1994.

Meincke, J., B. Rudels, and H. J. Friedrich, The Arctic Ocean-Nordic Seas thermohaline system, ICES J. Mar. Sci., 54, 283-299, 1997.

Mosby, H., Water, salt and heat balance in the North Polar Sea and of the Norwegian Sea, Geofys. Publ., 24, 289-313, 1962.

Paquette, R. G., R. H. Bourke, I. F. Newton, and W. F. Perdue, The east Greenland Polarfront in autumn, J. Geophys. Res., 90, 4866-4882, 1985.

Parsons, A. R., R. H. Bourke, R. D. Muench, C.-S. Chiu, J. F. Lynch, J. H. Miller, A. J. Plueddemann, and R. Pawlowicz, The Barents Sea Polar Front in summer, J. Geophys. Res., 101, 14,201-14,221, 1996.

Pickart, R. S., and S. Lindstrom, A comparison of techniques for referencing geostrophic velocities, J. Atmos. Oceanic Technol., 11, 814-824, 1994.

Pollard, R. T., and J. Read, A method of calibrating shipmounted acoustic Doppler profilers and the limitations of gyro compasses, J. Atmos. Oceanic. Technol., 6, 859-865, 1989.

Rodionov, V. B., On the mesoscale structure of the frontal zones in the Nordic Seas, J. Mar. Syst., 3, 127-139, 1992.

Rudels, B., On the mass balance of the Polar Ocean, with special emphasis on the Fram Strait, Norsk Polarinst. Skrifter, 188, 1-53, 1987.

Schneider, W., and G. Budéus, On the generation of the Northeast Water Polynya, J. Geophys. Res., 100, 4269-4286, 1995.

Smith, D. C., IV, and A. A. Bird, The interaction of an ocean eddy with an ice edge ocean jet in a marginal ice zone, J. Geophys. Res., 96, 46754689, 1991.

Swift, J. H., The Arctic Waters, in The Nordic Seas, edited by B. G. Hurdle, pp. 124-153, Springer-Verlag, New York, 1986.

Swift, J. H., and K. Aagaard, Seasonal transitions and water mass formation in the Iceland and Greenland seas, Deep Sea Res., 28, 1107-1129, 1981.

Swift, J. H., E. P. Jones, K. Aagaard, E. C. Carmack, M. Hingston, R. W. MacDonald, F. A. McLaughlin, and R. G. Perkin, Waters of the Makarov and Canada basins, Deep Sea Res., 44, 1503-1529, 1997.

Timofeyev, V. T., The movement of Atlantic Water and heat into the Arctic Basin, Deep Sea Res., 9, 358-361, 1962.

Timofeyev, V. T., Interaction of the Arctic Ocean Waters with Atlantic and Pacific waters, Okeologiya, 3, 569-578, 1963.

Trangeled, S., Oceanography of the Norwegian and Greenland Seas and Adjacent Areas, vol. 2, Survey of 1870-1970 Literature, Saclant ASW Res. Cent. Memo. SM-47, La Spezia, Italy, 1974.

van Aken, H. M., G. Budéus, and M. Hähnel, The anatomy of the Arctic Frontal Zone in the Greenland Sea, J. Geophys. Res., 100, 15,999$16,014,1995$

Woodgate, R. A., E. Fahrbach, and G. Rohardt, Structure and transports of the East Greenland Current at $75^{\circ} \mathrm{N}$ from moored current meters, J. Geophys. Res., 104, 18,059-18,072, 1999.

Zaitsev, G. N., M. V. Fedosov, N. L. Iljina, and I. A. Ermachenko, Components of the water: Thermic and chemical budget of the Greenland and Norwegian seas, Rapp. Cons. Explor. Mer., 149, 46-52, 1961

G. Budéus, B. Cisewski, and G. Krause, Alfred-Wegener-Institut für Polar- und Meeresforschung, Columbusstrasse, D-27568 Bremerhaven, Germany. (gbudeus@awi-bremerhaven.de; bcisewski@awi-bremerhaven. de; gkrause@awi-bremerhaven.de) 